\title{
PREMUNIZAÇÃO DA ABOBOREIRA HÍBRIDA TETSUKABUTO E DE MELANCIA PARA O CONTROLE DO MOSAICO CAUSADO PELO
}

\author{
Papaya ringspot virus - type $W$
}

\section{PAULO ROGÉRIO PARENTE dIAS}

Engenheiro Agrônomo

Orientador: Prof. Dr. JORGE ALBERTO MARQUES REZENDE

Dissertação apresentada à Escola Superior de Agricultura "Luiz de Queiroz", Universidade de São Paulo, para obtenção do título de Mestre em Agronomia. Área de Concentração: Fitopatologia.

PIRACICABA

Estado de São Paulo - Brasil

Agosto - 2000 


\section{Dados Internacionais de Catalogação na Publicação (CIP) DIVISÃo DE BIBLIOTECA E DOCUMENTAÇÃO - Campus "Luiz de Queiroz"/USP}

Dias, Paulo Rogério Parente Premunização da aboboreira híbrida Tetsukabuto e de melancia para o controle do mosaico causado pelo Papaya ringspot virus - type W / Paulo Rogério Parente Dias. - Piracicaba, 2000.

$59 \mathrm{p}$.

Dissertação (mestrado) - - Escola Superior de Agricuitura Luiz de Queiroz, 2000. Bibliografia.

1. Abóbora híbrida 2. Imunização 3. Melancia 4. Mosaico-da-melancia 5. Virus fitopatogênico l. Título

CDD 635.62

Rermitida a cópia to tol ou parcial deste documento, desde que citada a fonfe $=0$ autor? 
À memória dos meus avós,

Avô Dias e Avó Dina, dedico.

Aos meus pais, José Carlos e Vera e à minha irmã Mirela, ofereço. 


\section{AGRADECIMENTOS}

A Deus, luz dos caminhos da vida.

À minha família, em especial aos meus pais e à minha irmã sempre presentes nos momentos de alegria ou de tristeza, com amor e esperança.

À minha querida avó Leonor pelos conselhos e pela força contagiosa na sua alegria de viver.

Ao Prof. Dr. Jorge A.M. Rezende pela seriedade, profissionalismo, excepcional orientação, amizade e confiança depositada.

À companheira Érica Frazão Pereira pelo apoio, amor e compreensão.

Aos colegas fitopatologistas e, principalmente, aos amigos Ricardo Gioria e Marcus A. Bertocco Jr. pela valiosa amizade formada.

Ao Sr. Pedro C. Arthuso que colaborou nos trabalhos de casa de vegetação do Departamento de Entomologia, Fitopatologia e Zoologia Agrícola da ESALQ-USP e de campo, em Anhembi-SP.

Aos agricultores Umberto Calderan e Alexandre Toti pelo auxílio nos experimentos de campo.

Ao Prof. Dr. José Eduardo Corrente do Departamento de Matemética e Estatística da ESALQ-USP pelo auxílio nas análises estatísticas dos dados deste trabalho. 
Ao Dr. Hugo Kuniyuki e ao Dr. Valdir A. Yuki, do Centro de Fitossanidade, Instituto Agronômico de Campinas - SP, Dr. Elliot W. Kitajima, NAP/MEPA, ESALQ/USP, Piracicaba - SP, pela revisão do manuscrito e sugestões apresentadas.

À FAPESP pela concessão de bolsa de estudos, que garantiu o pleno desenvolvimento dos trabalhos.

Ao Departamento de Entomologia, Fitopatologia e Zoologia Agrícola da ESALQ-USP pela oportunidade de realização do curso de pós graduação (Mestrado) em Fitopatologia.

Aos professores, funcionários e colegas que contribuíram direta ou indiretamente na conquista deste Título de Mestre em Agronomia. 


\section{SUMÁRIO}

Página

RESUMO

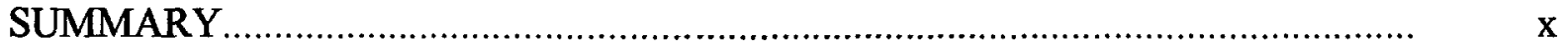

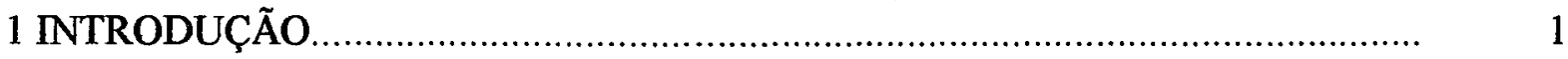

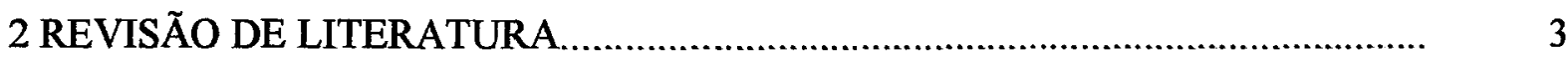

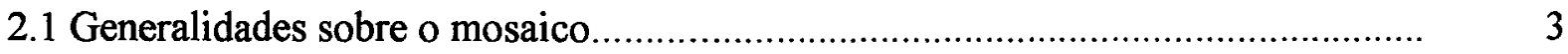

2.2 Generalidades sobre o controle do mosaico.................................................. 5

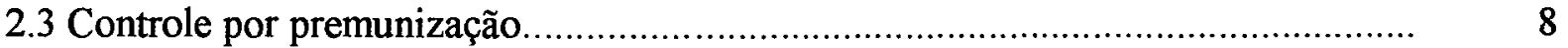

3 PREMUNIZAÇÃO DA ABÓBORA HÍBRIDA TETSUKABUTO PARA O

CONTROLE DO MOSAICO CAUSADO PELO Papaya ringspot virus- type $W$ -

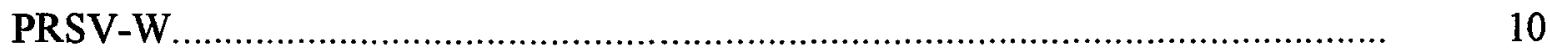

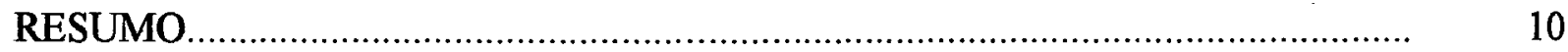

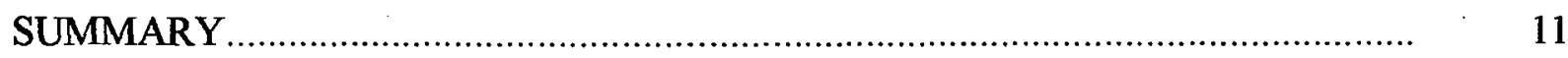

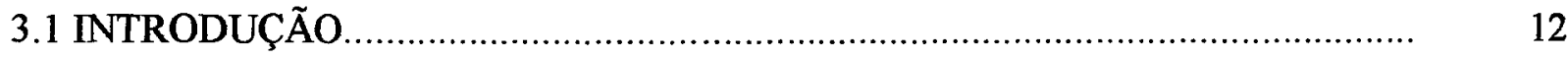

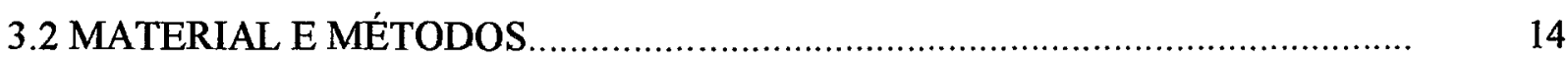

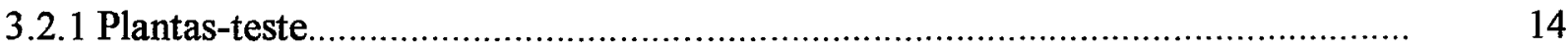

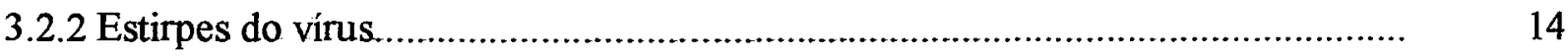

3.2.3 Inoculação mecânica...................................................................... 14

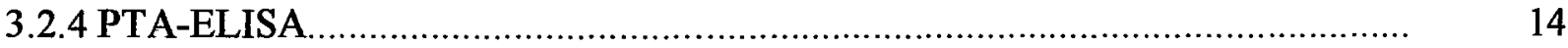

3.2.5 Teste de recuperação das estirpes do PRSV-W...................................... 15

3.2.6 Testes de proteção em casa de vegetação...................................................... 15

3.2.7 Testes de proteção em campo......................................................... 16

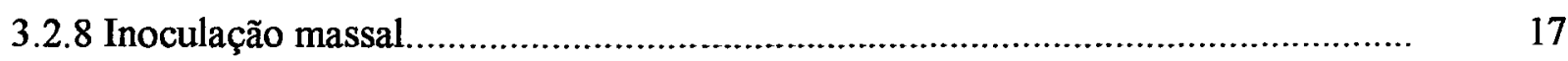

3.2.9 Análise estastística.................................................................... 18

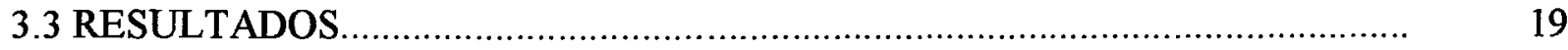

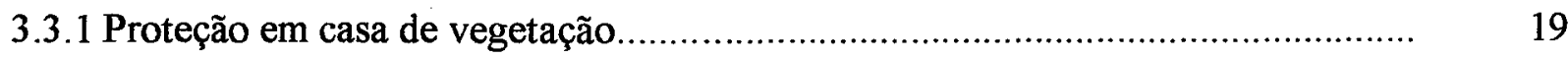

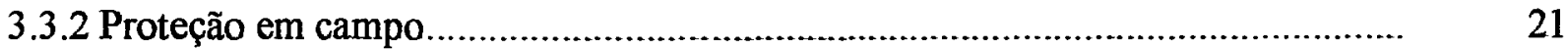




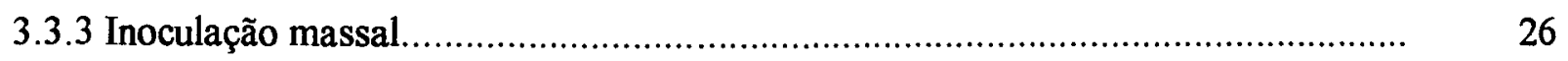

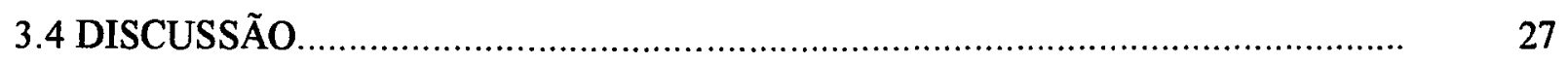

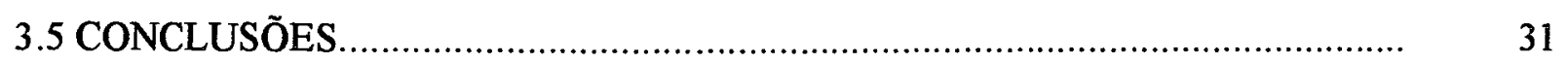

4 PROBLEMAS NA PREMUNIZAÇÃO DE MELANCIA PARA O

CONTROLE DO MOSAICO CAUSADO PELO Papaya ringspot virus- type $W$ PRSV-W.

RESUMO

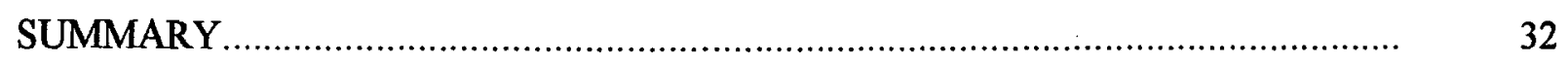

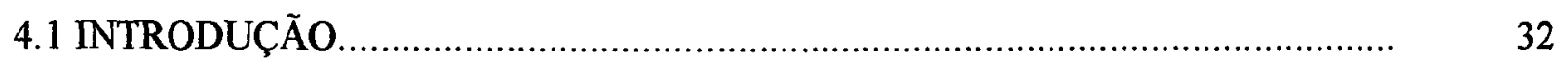

4.2 MATERIAL E MÉTODOS......................................................................... 34

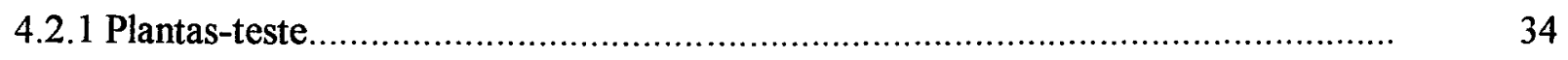

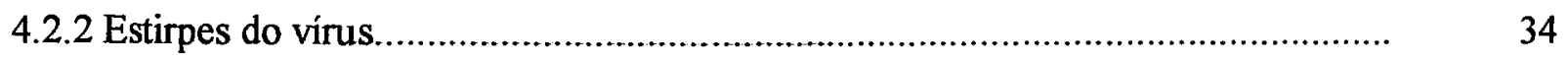

4.2.3 Inoculação mecânica....................................................................................

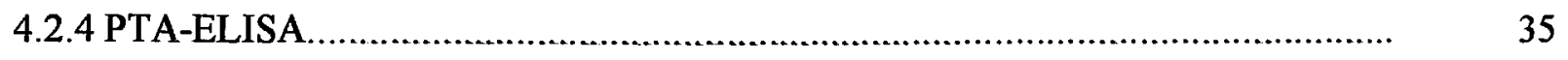

4.2.5 Teste de recuperação das estirpes do PRSV-W............................................... 35

4.2.6 Testes de proteção em casa de vegetação........................................................... 35

4.2.7 Testes de proteção em campo ........................................................................ 36

4.2.8 Análise estastística....................................................................................... 37

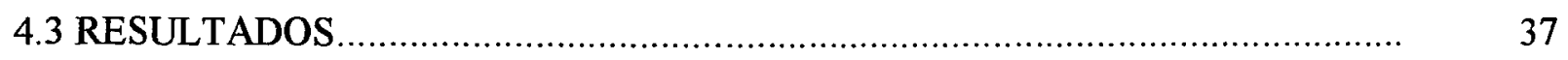

4.3.1 Proteção em casa de vegetação........................................................................

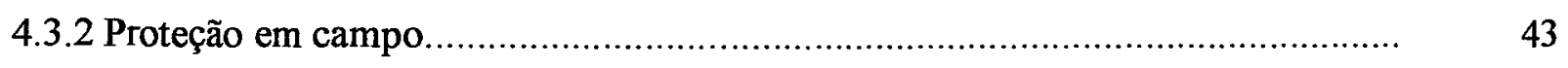

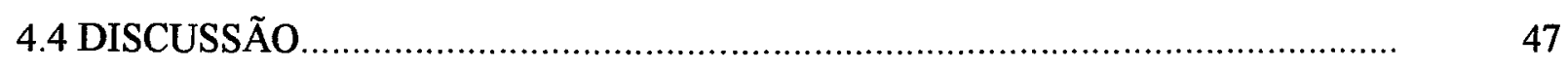

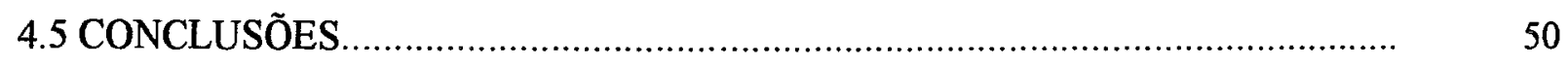

5 CONCLUSÕES GERAIS............................................................................... 50

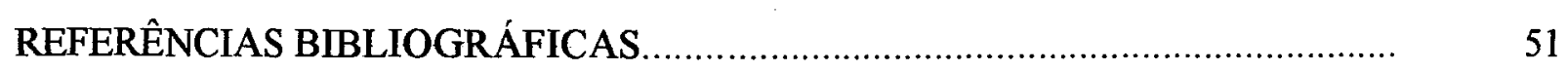




\title{
PREMUNIZAÇÃO DA ABOBOREIRA HÍBRIDA TETSUKABUTO E DE MELANCIA PARA O CONTROLE DO MOSAICO CAUSADO PELO
}

\author{
Papaya ringspot virus - type $W$
}

\author{
Autor: Paulo Rogério Parente Dias \\ Orientador: Prof. Dr. Jorge Alberto Marques Rezende
}

\section{RESUMO}

O Papaya ringspot virus - type $W$ - PRSV-W é uma espécie do gênero Potyvirus que infecta cucurbitáceas, entre as quais a aboboreira híbrida do tipo Tetsukabuto e a melancia. Esse vírus é o de maior incidência no Estado de São Paulo, é transmitido por afídeos, provoca sintomas do tipo mosaico foliar, redução do desenvolvimento vegetativo das plantas, deformações em folhas e frutos e redução significativa na quantidade e qualidade dos produtos. Com o objetivo de reduzir os danos provocados pelo PRSV-W, estudou-se o efeito protetor de estirpes fracas do vírus (PRSV-W-1 e PRSV-W-2) como forma de controle do mosaico em aboboreira Tetsukabuto e em melancia, em casa de vegetação e em campo. Os experimentos com a Tetsukabuto em casa de vegetação mostraram que as estirpes PRSV-W-1 e PRSV-W-2 protegeram as plantas contra a estirpe comum de Campinas (PRSV-W-C). Nos experimentos em campo, compararam-se o desenvolvimento e a produção de plantas sadias expostas à infecção natural, plantas inoculadas com a estirpe comum PRSV-W-C e premunizadas com as estirpes PRSV-W-1 e PRSV-W-2. No primeiro experimento, as plantas premunizadas produziram aproximadamente 2,0 vezes mais frutos/planta (peso) do que as infectadas com estirpes comuns do vírus. Qualitativamente, 83,7\% dos frutos colhidos das plantas protegidas foram classificados como comerciais, enquanto que as infectadas com as estirpes comuns produziram somente $25 \%$ de frutos dessa categoria. No segundo experimento, frutos colhidos das plantas premunizadas foram, aproximadamente, 1,6 vezes maiores (peso) do que aquelas infectadas com estirpes comuns do vírus. No entanto, $97,1 \%$ 
dos frutos colhidos das plantas protegidas foram comerciais, em contraste com $2,1 \%$ de frutos dessa classe colhidos de plantas não protegidas, infectadas naturalmente com estirpes comuns do vírus. A premunização massal de mudas de Tetsukabuto, com inóculo aplicado com uma pistola para pintura, sob pressão, mostrou eficiência variável de $63 \%$ a $79 \%$. Mesmo assim, a maioria das plantas não infectadas foram naturalmente inoculadas com as estirpes fracas em campo, por meio da ação dos afideos vetores. Os resultados da proteção em melancia mostraram que a estirpe PRSV-W-1 protegeu as plantas contra as estirpes comuns PRSV-W-C, PRSV-W-B (Botucatu) e PRSV-W-P (Petrolina), separadamente, em testes em casa de vegetação. Nos experimentos em campo, compararam-se o desenvolvimento e a produção de plantas de melancia dos cultivares Crimson Sweet e Crimson Tide premunizadas com as estirpes PRSV-W-1 e PRSV-W-2, não premunizadas expostas à infecção natural e inoculadas com a estirpe PRSV-W-C no estádio cotiledonar. A proteção também foi eficiente em condições de campo, porém, as plantas protegidas do cultivar Crimson Sweet tiveram uma redução no peso médio de frutos por planta de, aproximadamente, 2,4 e 1,2 vezes, em comparação às plantas não protegidas que estavam sadias, no primeiro e no segundo teste, respectivamente. O mesmo fato ocorreu com o cultivar Crimson Tide, no qual registrou-se uma redução de 1,7 vezes, aproximadamente, em um único teste. Além da redução na produção, outro problema encontrado na premunização da melancia foi a necessidade de duas inoculações sucessivas das mudas, em dias consecutivos, para aumentar a freqüência de plantas protegidas. Os resultados obtidos permitem sugerir a premunização da abóbora Tetsukabuto para plantios comerciais. Quanto à melancia, acredita-se que a premunização possa até ser valiosa nas regiões e/ou épocas de alta incidência do PRSV-W. Porém, estudos adicionais são necessários para encontrar estirpes fracas do vírus que infectem mais facilmente as mudas de melancia e que não causem danos tão acentuados na produção. 


\title{
CROSS PROTECTION OF HYBRID SQUASH TETSUKABUTO AND WATERMELON FOR THE CONTROL OF Papaya ringspot virus - type $W$
}

\author{
Author: Paulo Rogério Parente Dias \\ Adviser: Prof. Dr. Jorge Alberto Marques Rezende
}

\section{SUMMARY}

Papaya ringspot virus - type $W$ - PRSV-W is a specie of the genus Potyvirus that infects cucurbitaceae, including the hybrid squash Tetsukabuto and watermelon. PRSV-W is the most prevalent virus in the State of São Paulo, it is transmited by aphids, causes mosaic symptoms, reduction on plant development, leaf and fruit deformation and significative reduction in the quantity and quality of the products. The objective of this work was to evaluate the protective effect of two mild strains of the virus (PRSV-W-1 and PRSV-W-2) for controlling the disease in hybrid squash Tetsukabuto and watermelon, under greenhouse and field conditions. Greenhouse experiments with Tetsukabuto showed that both mild strains protected the plants against infection with the common strain from Campinas (PRSV-W-C). Two field trials were carried out in order to evaluate the protective effect of the mild strains on plant development and fruit yield. In the first field trial, protected plants yielded approximately 2.0 times more fruits/plant (weight) than plants naturaly infected with common strains of the virus. Protected plants and plants infected with common strains of the virus yielded $83.7 \%$ and $25 \%$ of marketable fruits, respectively. In the second field trial, protected plants yielded approximately 1.6 times more fruits/plant (weight) than plants infected with common strains of the virus, with $97,1 \%$ of marketable fruits. Only $2,1 \%$ of marketable fruits were harvested from unprotected plants, naturaly infected with the common strain. Mass inoculation of hybrid squash seedlings was evaluated with a paint spray gun attached to an air compressor. Efficiency of mild strain infection varied from $63 \%$ to $79 \%$. The majority of remaining healthy plants were naturally infected with the mild strains during the growth cycle 
of the crop, through the action of aphid vectors. The mild strain PRSV-W-1 also protected watermelon plants against the effects of three common strains, PRSV-W-C, PRSV-W-B (Botucatu) and PRSV-W-P (Petrolina), separately, in greenhouse tests. Field tests were carried out to evaluate the protective effect of the mild strains PRSV-W-1 e PRSV-W-2 on watermelon cvs. Crimson Sweet and Crimson Tide. Protection was also effective under field conditions. However, protected plants of 'Crimson Sweet' showed a reduction on the average weight of fruit per plant of, aproximately, 2.4 and 1.2 times, as compared to the yield of healthy plants, in the first and second trials, respectively. Yield reduction on protected 'Crimson Tide' was aproximately 1.7 times in one trial. In addition to yield reduction, another problem for protecting watermelon was the requirement of two successive inoculations of the seedling, on consecutive days, to increase the frequence of infected plants. Mild strains protection can be recommended for the control of PRSV-W in hybrid squash crops. In spite of the problems in watermelon, cross protection may be valuable for this species in those regions and/or season with high incidence of PRSV-W. Studies are necessary to select mild strains of PRSV-W that are more infective on watermelon seedlings and do not cause significant yield reduction on protected plants. 


\section{INTRODUÇÃO}

A cultura de cucurbitáceas no Brasil representa uma importante fonte de renda para centenas de agricultores espalhados por todo o país, destacando-se aquelas áreas próximas aos grandes centros urbanos, como São Paulo, Rio de Janeiro, Belo Horizonte, Brasília e Porto Alegre.

As cucurbitáceas se relacionam principalmente com o valor alimentício e culinário de algumas espécies do gênero Cucurbita (abóbora, abobrinha), Cucumis (melões, pepinos), Sechium (chuchu) e Citrullus (melancias).

Entre as abóboras, as híbridas interespecíficas (Cucurbita maxima Duch. ex Lam. $\mathrm{C}$. moschata Duch. ex Poir.), conhecidas como abóboras do tipo Tetsukabuto, Kabotia ou abóbora japonesa, tem apresentado um aumento na área plantada nos últimos anos. Muitos desses híbridos obtidos no Brasil ('AG 90', 'Agroflora 12', 'Lavras 1', 'Samanta' e outros) ou no exterior ('Kiowa', 'Sakata', 'Takayama' e outros), apresentam, em geral, algumas vantagens sobre cultivares de abóbora, como vigor, rápida resposta à adubação, uniformidade no tamanho e coloração dos frutos, que são resistentes ao manuseio, ao transporte e ao armazenamento. Em solos de alta fertilidade, a aboboreira do tipo Tetsukabuto pode produzir de 20.000 a 30.000 flores/ha, que se caracterizam pela macho esterilidade. A frutificação do híbrido, portanto, pode ser obtida de duas maneiras: a) sexuadamente, utilizando-se pólen de uma espécie polinizadora, como a moranga (C. maxima), que deve ocupar de 15 a $20 \%$ da 
área cultivada e b) assexuada ou partenocarpicamente, realizada com aplicação de hormônio vegetal com características de auxina, como o ácido 2,4-diclorofenoxiacético (Pereira, 1999).

Outra cucurbitácea, que se destaca economicamente no pais, é a melancia (Citrullus lanatus (Thunb.) Matsum. \& Nakai.), encontrando-se entre as cinco mais importantes hortaliças cultivadas no Brasil. Em 1994, foram registrados no pais 72.726 ha de área plantada, com produção de $149.321 \mathrm{t}$. Nesse mesmo ano, constatou-se que a área plantada e a produção, respectivamente, em alguns estados brasileiros foram: Rio Grande do Sul, 16.095 ha e 39.559 t; Bahia, 11.055 ha e 27.664 t; Goiás, 7.974 ha e 20.325 t e São Paulo, 7.450 ha e 25.043 t (Anuário Estatístico do Brasil, 1997). Em 1996, no CEAGESP de São Paulo, o volume comercializado dessa hortaliça foi de 35.842 t. Já, em 1997, o volume aumentou para 49.525 t comercializadas (FNP, 1999). Em 1999, no estado de São Paulo, a área cultivada de melancia, registrada, foi de 9.283 ha (Instituto de Economia Agrícola - IEA e Coordenadoria de Assistência Técnica Integral - CATI, 2000).

As abóboras híbridas, bem como as melancias, além de outras cucurbitáceas, estão sujeitas ao ataque de diversos patógenos que podem causar danos à produção, tanto quantitativo como qualitativo. Entre esses patógenos, encontram-se os vírus que, nas épocas de maior incidência, geralmente provocam prejuízos elevados no cultivo dessas hortaliças. Dentre os oito vírus já relatados no Brasil, infectando plantas da familia Cucurbitaceae, há predominância do Papaya ringspot virus - type $W$ (PRSV-W), na maioria dos estados. Esse vírus é uma espécie do gênero Potyvirus, transmitido por afideos de maneira não persistente, cujo círculo de hospedeiras está praticamente restrito às espécies de cucurbitáceas.

Devido ao fato de o PRSV-W encontrar-se endêmico nas áreas produtoras de cucurbitáceas no país, as medidas de controle devem ser desenvolvidas de modo que funcionem em convivência com o patógeno, pois a sua erradicação é impraticável. Embora existam diversas recomendações para o controle do mosaico, causado pelo PRSV-W, tais como, a eliminação de hospedeiras contidas na vegetação espontânea que ocorrem próximas da área de plantio, programas de controle de afídeos com inseticidas, pulverizações com óleos minerais, uso de substâncias reflectivas e uso de variedades resistentes ou tolerantes, quando disponíveis (Lovisolo, 1980), nenhuma delas tem sido eficiente no controle dessa virose em abóboras híbridas e em melancia. 
Nos últimos anos, estudos sobre o uso da premunização para o controle da viroses em cucurbitáceas têm aberto uma nova avenida de controle em convivência, com resultados altamente promissores. Para exemplificar, pode-se citar o controle do mosaico amarelo da abobrinha de moita, causado pelo Zucchini yellow mosaic virus (ZYMV) na França (Lecoq et al., 1991), Taiwan (Wang et al., 1991), Inglaterra (Walkey et al., 1992), Hawaii (Cho et al., 1992) e em Israel (Yarden et al., 2000); do mosaico do pepino (Cucumber mosaic virus CMV) em melão nos EUA (Montasser et al., 1998) e do mosaico da abobrinha causado pelo PRSV-W no Brasil (Rezende \& Pacheco, 1998; Rezende et al., 1999). No caso brasileiro, a premunização já vem sendo utilizada para o controle do mosaico em plantios comerciais de abobrinha de moita e de abóbora 'Menina Brasileira'.

Diante desses fatos, o presente trabalho teve por objetivo avaliar o efeito da premunização no controle do mosaico causado pelo PRSV-W em abóbora híbrida do tipo Tetsukabuto e em melancia. Além disso, procurou-se desenvolver um método de inoculação massal de mudas de abóbora híbrida.

\section{REVISÃO DE LITERATURA}

\subsection{Generalidades sobre o mosaico}

Em geral, as cucurbitáceas estão sujeitas a doenças causadas por virus, sendo que uma das mais importantes é a do mosaico das folhas, causado pelo vírus do mosaico do mamoeiroestirpe melancia (Papaya ringspot virus - type $W$, PRSV-W). Há anos, esse vírus vem sendo considerado predominante em diversos estados brasileiros, como Pará (Albuquerque et al., 1972); Distrito Federal (Cupertino et al., 1974); Piauí (Lima et al, 1980); Rio Grande do Norte (Lima \& Vieira, 1992), Minas Gerais (Pavan et al., 1989), São Paulo e Rio de Janeiro (Costa et al. 1972; Kitajima et al.1984 e Lin et al., 1980). Exceção foi constatada em algumas áreas do Submédio São Francisco, onde o Watermelon mosaic virus - 2 (WMV-2) apareceu em primeiro lugar (68,7 \%), seguido pelo PRSV-W (31,2 \%) (Cruz et al., 1999). Em São Paulo, Yuki et al. (2000) confirmaram que o PRSV-W continua prevalecente no Estado, seguido pelo Zucchini yellow mosaic virus (ZYMV) e Zucchini lethal chlorosis virus 
(ZLCV). Nos casos das abóboras híbridas e das melancias, constataram incidências médias do PRSV-W de 45,8\% e $68,7 \%$, respectivamente.

O PRSV-W pode ser encontrado tanto em áreas tropicais como subtropicais (Purcifull et al., 1984). Infecta apenas espécies de duas famílias de dicotiledôneas: Cucurbitaceae e Chenopodiaceae, sendo que, nessa última, os sintomas são localizados (Purcifull et al., 1984). Não há relatos de estirpes brasileiras desse vírus causando infecção local em Chenopodiaceae.

Esse vírus é constituído por RNA de fita simples, senso positivo, pertencente ao gênero Potyvirus, da família Potyviridae. Apresenta partículas flexuosas de aproximadamente $780 \mathrm{~nm}$ de comprimento por $12 \mathrm{~nm}$ de diâmetro (Purcifull et al., 1984). Naturalmente, é transmitido por diversas espécies de afídeos de maneira não persistente. Adlerz (1974) demonstrou que as espécies mais eficientes na transmissão do PRSV-W foram Aphis gossypii Glover (92\%), A. spiraecola Patch. (80\%), Myzus persicae Sulzer (69\%) e A. craccivora Koch. (59\%). Giampan \& Rezende (1999), trabalhando com estirpes fracas e comuns do PRSV-W, verificaram que a espécie $M$. persicae foi a mais eficiente na transmissão dessas estirpes, seguida por A. gossypii, Toxoptera citricidus Kirkaldy e Lipaphis erysimi Kaltenbach. O PRSV-W também pode ser transmitido através de instrumentos de corte, conforme demonstrado em estudos realizados com abobrinha de moita 'Caserta' (Yuki et al., 1996). Esse resultado é um indicativo de que o patógeno pode ser transmitido para plantas sadias por ocasião da colheita dos frutos, aumentando com isso a sua disseminação. Não há relatos da transmissão do PRSV-W por sementes de cucurbitáceas (Kurozawa \& Pavan, 1997). A ocorrência de diferentes espécies de afídeos durante o desenvolvimento dos hospedeiros é considerada importante na disseminação do vírus (Pavan, 1985). Adlerz (1974) verificou que a disseminação do PRSV-W está relacionada com o pico de migração de várias espécies de afídeos.

As cucurbitáceas, em geral, são altamente sensíveis à infecção pelo PRSV-W. O vírus causa doença do tipo mosaico e a severidade dos sintomas depende da espécie de cucurbitácea afetada. Além do sintoma de mosaico nas folhas, as plantas doentes mostram uma redução drástica no limbo foliar, encarquilhamento e rugosidade das folhas e redução no desenvolvimento vegetativo (Provvidenti, 1996). Os danos na produção, provocados pelo PRSV-W, podem ser significativos, especialmente nas épocas de maior incidência e/ou 
quando a infeç̧ão das plantas ocorre precocemente. Esses danos podem ser tanto quantitativos como qualitativos, pois além da redução no tamanho e no peso dos frutos, estes podem ficar manchados e/ou deformados. Poucos são os trabalhos que mostram resultados quantitativos de danos causados por esse vírus em espécies de cucurbitáceas. Yuki et al. (1991) verificaram que a redução na produção, no caso de abobrinha de moita 'Caserta', está diretamente relacionada com a época de infecção das plantas. Quando esta ocorre antes do florescimento, os danos na produção podem atingir 100\%. Diferentemente, Demski \& Chalkley (1972) observaram que, independentemente do estádio em que ocorreu a infecção, os danos na produção de abobrinha de moita foram da ordem de $90 \%$. Estudos realizados na Austrália, com plantas de abóbora (C. maxima cv. Queensland Blue) inoculadas nas primeiras semanas de idade, mostraram uma redução na produção de 62 a $79 \%$ (Herrington, 1987). Plantas inoculadas por ocasião do florescimento, ou logo depois desse, tiveram uma produção semelhante à das plantas sadias. Observações feitas na região do Submédio São Francisco, que se destaca como importante produtora de melancia no Brasil, indicaram a ocorrência de danos de até $100 \%$ em lotes de projetos de irrigação, devido à alta incidência do PRSV-W, com base em Lima ${ }^{1}$. Não parece haver relatos sobre os danos causados por esse Potyvirus em abóbora híbrida do tipo Tetsukabuto.

\subsection{Generalidades sobre o controle do mosaico}

O uso de cultivares ou híbridos resistentes é, geralmente, a principal recomendação de controle de fitoviroses. Apesar de ser uma das formas mais eficientes de controle, esforços continuam sendo dispendidos para o desenvolvimento de cultivares comerciais de abóbora híbrida e de melancia, com níveis satisfatórios de resistência, para serem utilizados comercialmente. Fontes de resistência ou tolerância ao PRSV-W têm sido localizadas em um limitado número de espécies de cucurbitáceas.

Maluf \& Sousa (1984), trabalhando com duas introduções de C. maxima (CMAX-001 e CMAX-004) verificaram que a CMAX-001 apresentou alto nível de resistência ao Watermelon mosaic virus -1 - WMV-1, atualmente denominado PRSV-W. Kuabara et al.

\footnotetext{
${ }^{1}$ Lima, M.F. (EMBRAPA Semi-Árido, Petrolina). Comunicação pessoal, 1998.
} 
(1987) constataram que de 91 populações de abóboras (Cucurbita $\mathrm{sp}$.) estudadas, apenas 14 foram resistentes ao PRSV-W, com potencial de utilização como fontes de resistência. Kuabara \& Costa (1987), em trabalhos complementares, obtiveram o cultivar Piramoita, através do cruzamento de abóbora ( $C$. moschata $\mathrm{cv}$. Menina Brasileira), que apresenta um grau satisfatório de resistência ao PRSV-W, com a abobrinha de moita (C. pepo), e posteriores retrocruzamentos com a 'Menina Brasileira'. O cultivar Piramoita apresentou resistência ao vírus, semelhante a da abóbora 'Menina Brasileira'.

Outra espécie com alto grau de resistência ao PRSV-W, a abóbora C. ecuadorensis Cutler \& Whitaker, também tem sido utilizada em programas de melhoramento genético, com a finalidade de transferência dessa característica a outras espécies do mesmo gênero (Greber \& Herrington, 1980; Herrington et. al., 1989; Herrington et al., 1991). Estudos sobre a resistência envolvida em cruzamentos entre $C$. ecuadorensis e $C$. maxima mostraram resultados diferentes. Enquanto Herrington et al. (1989) constataram tratar-se de herança poligênica aditiva, em geral, Tasaki \& Dusi (1990) demonstraram que a resistência é determinada por um simples gene dominante.

Em melancia, Hojo et al. (1991b), avaliando a resistência de vinte cultivares e híbridos, inoculados com a mais agressiva estirpe do PRSV-W, denominada Ab-081 (Hojo et al., 1991a), constataram que apenas a introdução BT-8501; originária da África, mostrou-se tolerante ao mosaico. Essa introdução também apresentou tolerância ao ZYMV e ao WMV-2 (Sittolin, 1998), além da resistência ao CMV anteriormente relatada por Pavan \& Silva (1990). No caso da resistência da melancia BT-8501 ao ZYMV e ao WMV-2, Sittolin (1998) verificou ser governada por dois pares de genes recessivos.

Trabalhos recentes de engenharia genética vêm contribuindo para o desenvolvimento de plantas transgências resistentes a vírus em cucurbitáceas. Os genes que codificam as proteínas da capa proteica do ZYMV, WMV-2 e CMV, respectivamente, foram introduzidos em abobrinha de moita e melão, permitindo o desenvolvimento de plantas com resistência múltipla a esses vírus (Arce-Ochoa et al., 1995; Fuchs \& Gonsalves, 1995 e Glough \& Hamm, 1995; Fuchs et al., 1997).

A eliminação de plantas hospedeiras que ocorrem próximas às áreas de cultivo; o controle de afídeos vetores, que agem na fase vegetativa mais intensa, com inseticidas e óleos 
minerais ou a redução da sua atividade através da cobertura do solo com casca de arroz, ou outras superfícies refletoras, são outras alternativas de controle recomendadas. $\mathrm{O}$ uso de inseticidas para a redução da incidência do PRSV-W em cucurbitáceas não mostrou resultados satisfatórios (Chalfant et al., 1977; Simons \& Zitter, 1980; Yuki, 1990). Tal ineficiência deve-se, provavelmente, ao fato do inseticida ser incapaz de matar os afideos antes da inoculação do vírus na planta. Em alguns casos, acredita-se que podem até provocar excitação dos afideos durante as picadas de prova, aumentando a incidência do vírus na cultura (Broadbent, 1969). No caso de óleos minerais, Orozco et al. (1994) mostraram resultados experimentais positivos no controle de viroses de cucurbitáceas em outros países. No Brasil, o óleo vegetal Natur' oil e o mineral Triona B não surtiram efeito para o controle do PRSV-W em abobrinha de moita (Yuki, 1990).

Casca de arroz, superficies aluminizadas e plásticos coloridos também têm sido testados para o controle do mosaico em cucurbitáceas, com resultados experimentais satisfatórios (Moore et al., 1965; Adlerz \& Everett, 1968; Costa \& Costa, 1971; Chalfant et al., 1977; Wyman et al., 1979; Perring et al., 1989; Yuki, 1990; Brown et al., 1993; Orozco et al., 1994; Summers et al., 1995). Yuki (1990) verificou que faixas de casca de arroz, com 30 $\mathrm{cm}$ de largura, aplicadas nas linhas de plantio de abobrinha 'Caserta', reduziram a incidência do mosaico (PRSV-W). Apesar desse resultado, não se conhece a utilização dessa técnica em culturas comerciais de abobrinha de moita, ou de outras cucurbitáceas, provavelmente devido ao fato da necessidade de uma grande quantidade do material para cobrir a área do plantio. Perring et al. (1989) demonstraram a eficiência da utilização de uma cobertura de polypropyleno e de poliester na repelência de afídeos encontrados no campo e o seu efeito na redução da incidência do ZYMV e do WMV-2 em melão. Summers et al. (1995), comparando coberturas reflectivas, verificaram que polietileno prateado e latex sintético prateado, solúvel em água e pulverizado sobre o solo, repeliram afideos com maior eficiência e atrazaram a infecção de plantas de abobrinha de moita. Porém, o uso em larga escala desses materiais torna-se proibitivo para alguns agricultores devido ao alto custo de implantação. Além disso, há o problema ecológico associado ao descarte desses materiais após o cultivo, exceção para esse último composto à base de latex, que é biodegradável. 


\subsection{Controle de fitoviroses por premunização}

A premunização é uma técnica que tem por base o princípio da proteção, na qual plantas sistemicamente infectadas com uma estirpe do vírus, são protegidas contra a infecção e/ou manifestação de outras estirpes do mesmo vírus, posteriormente inoculadas. Quando a primeira estirpe inoculada é fraca, isto é, não provoca danos depreciativos, esse fenômeno passa a ter valor no controle da doença, conforme sugerido pela primeira vez por Salaman (1937) e Jonhson (1937).

Desde que o fenômeno da proteção foi constatado pela primeira vez nos trabalhos com o Tobacco ringspot virus (Wingard, 1928) e Tobacco mosaic virus (McKinney, 1929) em plantas de fumo (Nicotiana tabacum L.), outros estudos se seguiram no sentido de aplicação prática da proteção no controle de fitoviroses.

Trabalhos pioneiros nessa linha foram desenvolvidos por Posnette \& Todd (1955) para o controle do "swollen shoot" do cacaueiro (Theobroma cacao L.), na África, e por Simmonds (1959) para o controle do endurecimento dos frutos do maracujazeiro na Austrália. Enquanto na África os estudos foram descontinuados por vários anos, sendo reativados recentemente (Ollennu \& Owusu, 1989; Hughes \& Ollennu, 1994), na Austrália sabe-se que a premunização ainda é utilizada no controle do endurecimento dos frutos (Peasley \& Fitzell, 1981; Pares et al., 1985).

Na década de 70, duas outras viroses passaram a ser controladas por meio da premunização: o mosaico do tomateiro, causado pelo Tomato mosaic virus e a tristeza dos citros, induzida pelo Citrus tristeza virus. No primeiro caso, os trabalhos foram iniciados por Rast $(1972,1975)$, com a produção de uma estirpe fraca mutante, através do tratamento de estirpes comuns do vírus com ácido nitroso. Essa estirpe (MII-16) foi utilizada por vários anos na proteção de plantas de tomateiro na Holanda (Rast, 1975) e no Reino Unido (Channon et al., 1978), com ganhos na produção de frutos. Devido à quebra de proteção e ao desenvolvimento de cultivares resistentes de tomateiro (Fulton, 1986), a premunização nessa espécie não teve continuidade. No segundo caso, Müller \& Costa (1977), com a seleção de estirpes fracas do vírus da tristeza dos citros, obtiveram resultados positivos de proteção contra as estirpes comuns. Desde então, a utilização da premunização de laranjeira 'Pêra' em 
larga escala alcançou a marca de 50 milhões de árvores no Brasil, sem verificação de quebra de proteção (Salibe, 1987). Parece não haver registros de dados mais recentes do número de plantas premunizadas.

Um outro vírus que causa danos severos em tomateiro, pimentão e cucurbitáceas, em geral, o CMV, também já foi incluído em programas de premunização. Com a obtenção de duas estirpes protetoras do CMV, pela utilização de um RNA satélite que atenua os sintomas provocados pela estirpe comum do vírus, Tien et al. (1987), na China, obtiveram resultados promissores de proteção em pimentão, com redução de até $82 \%$ na incidência da doença e aumento na produção de até 55\%. Montasser et al. (1998) mostraram que plantas de melão premunizadas com uma estirpe fraca do CMV, em associação com o RNA satélite benígno, ficaram protegidas contra a infecção por estirpes comuns do vírus, em testes em casa de vegetação e em campo, no Estado de Maryland, E.U.A.

Resultados promissores também foram obtidos em cucurbitáceas, quando a premunização foi primeiramente proposta por Lecoq et al. (1989), para o controle do mosaico causado pelo ZYMV na França. Experimentos de campo neste país e em Taiwan mostraram a eficiência dessa técnica na proteção das plantas, com aumento significativo de produção. Na França, Lecoq et al. (1991) demonstraram que a produção de duas variedades de abobrinha de moita premunizadas foi 14,7 vezes maior do que a das plantas não protegidas. Em Taiwan, resultados obtidos por Wang et al. (1991) mostraram que a mesma estirpe fraca (ZYMV-WK) testada na França protegeu plantas de abobrinha de moita em campo. Ganhos na produção das plantas premunizadas, da ordem de $116 \%$ e $1256 \%$, foram obtidos no primeiro e no segundo ano, respectivamente. Resultados semelhantes com a estirpe ZYMV-WK foram obtidos por Cho et al. (1992), no Hawaii, Walkey et al. (1992), na Inglaterra e por Perring et al. (1995), em plantas de melão na Califórnia, EUA. No ano de 1999, quase 800 ha de melancia, abobrinha de moita e pepino (Cucumis sativus L.) foram plantados em Israel com mudas premunizadas com a estirpe fraca ZYMV-WK (Yarden et al., 2000).

Múltipla premunização de plântulas de pepino com estirpes atenuadas do CMV, ZYMV e WMV-2 também já foi estudada experimentalmente, porém constatou-se sinergismo entre as estirpes fracas desses vírus, com danos na produção. Assim sendo, a inoculação foi recomendada apenas nas estações do ano (verão e outono), quando os danos decorrentes da 
infecção com esses vírus são elevados e maiores do que aqueles provocados pelas estirpes fracas premunizantes (Kosaka \& Fukunishi, 1998).

No Brasil, estudos iniciados por Rezende et al. (1994) mostraram que estirpes fracas do PRSV-W, selecionadas de bolhas de folhas com mosaico, ofereceram alta proteção contra estirpes comuns em plantas de abobrinha de moita. Posteriormente, Rezende \& Pacheco (1998) relataram sobre a eficiência da premunização com as mesmas estirpes fracas para o controle da doença em campo e apresentaram a metodologia para aplicação da técnica em larga escala. Também tem sido verificado que a premunização com essas estirpes fracas do PRSV-W, combinada com a tolerância ao vírus, encontrada em abóbora rasteira 'Menina Brasileira', proporcionou um melhor controle da doença em campo, com aumento significativo na produção de frutos comerciais (Rezende et al., 1999).

\section{PREMUNização da ABóbora híbrida tetsukabuto para O CONTROLe do MOSAICO CAUSAdo PELO Papaya ringspot virus - type $W$ (PRSV-W)}

\section{RESUMO}

Neste trabalho, estudou-se o efeito protetor de estirpes fracas do Papaya ringspot virus - type $W$ (PRSV-W-1 e PRSV-W-2) no controle do mosaico causado por esse vírus em abóbora híbrida Tetsukabuto, em condiçães de casa de vegetação e de campo. Os experimentos em casa de vegetação mostraram que as estirpes fracas protegeram as plantas contra a estirpe comum de Campinas (PRSV-W-C). Nos experimentos em campo compararam-se o desenvolvimento e a produção de plantas sadias expostas à infecção natural, plantas inoculadas com a estirpe comum PRSV-W-C e premunizadas com as estirpes fracas PRSV-W-1 e PRSV-W-2. A proteção foi eficiente e as plantas premunizadas de dois experimentos independentes mostraram ganhos quantitativos e qualitativos na produção. No primeiro experimento, as plantas premunizadas produziram, aproximadamente, 2,0 vezes mais frutos/planta (peso) do que as infectadas com estirpes comuns do virus. Qualitativamente, $83,7 \%$ dos frutos colhidos das plantas protegidas foram classificados como comerciais, 
enquanto que as infectadas com estirpes comuns produziram somente $25 \%$ de frutos dessa categoria. No segundo experimento, frutos colhidos das plantas premunizadas foram 1,6 vezes maiores (peso) do que as plantas infectadas com estirpes comuns do vírus. No entanto, $97,1 \%$ dos frutos colhidos das plantas protegidas foram comerciais, em contraste com $2,1 \%$ de frutos dessa classe colhidos de plantas não protegidas, naturalmente infectadas com estirpes comuns do PRSV-W. A premunização massal de mudas de abóbora híbrida do tipo Tetsukabuto, com inóculo aplicado com uma pistola para pintura, sob pressão, mostrou eficiência variável de $63 \%$ a 79\%. Mesmo assim, a maioria das plantas não inoculadas foram naturalmente infectadas com as estirpes fracas em campo, por meio da ação dos afideos vetores. Esses resultados permitem sugerir a premunização como um método de controle do mosaico causado pelo PRSV-W também em plantios comerciais de abóbora híbrida do tipo Tetsukabuto.

\section{SUMMARY}

Protective effect of mild strains of Papaya ringspot virus - type W (PRSV-W-1 e PRSV-W-2) was studied for controlling of the disease in hybrid squash Tetsukabuto (Cucurbita maxima $\times$ C. moschata), under greenhouse and field conditions. Greenhouse experiments showed that the two mild strains protected plants of the hybrid squash against infection with the common strain PRSV-W-C. Two field trials were carried out in order to evaluate the protective effect of the mild strains on plant development and fruit yield. All preimmunized plants were protected against infection with common strains of the virus in both field experiments. In the first field trial, protected plants yielded approximately 2.0 times more fruits/plant (weight) than plants infected with common strains of the virus. Both, protected and unprotected plants yielded 83.7 and $25 \%$ of marketable fruits, respectively. In the second field trial, protected plants yielded approximately 1.6 times more fruits/plant (weight) than plants infected with common strains of the virus, with $97,1 \%$ of marketable fruits. Only $2,1 \%$ of marketable fruits were harvested from unprotected plants, naturaly infected with the common strain. Mass inoculation of hybrid squash seedlings was evaluated with a paint spray gun attached to an air compressor. Efficiency of mild strain infection varied from 63 to $79 \%$. The majority of remaining healthy plants were naturally protected during the 
growth cycle of the crop, through the action of aphid vectors. Mild strain protection can be recommended for the control of PRSV-W in hybrid squash crops.

\subsection{INTRODUÇÃO}

$\mathrm{O}$ vírus do mosaico do mamoeiro - estirpe melancia (Papaya ringspot virus - type $W$, PRSV-W) é um Potyvirus, transmitido de forma não persistente por diferentes espécies de afideos, encontrando-se disseminado por diversos países, sendo responsável por danos à produção de várias espécies da família Cucurbitaceae (Purcifull et al., 1984). No Brasil, o PRSV-W já foi relatado em vários Estados (Albuquerque et al., 1972; Costa et al., 1972; Cupertino et al., 1974; Lima et al., 1980; Lima \& Vieira, 1992; Pavan et al., 1989), como o vírus predominante na maioria deles. Em São Paulo, estudos recentes sobre a incidência de 5 vírus em cucurbitáceas confirmaram que o PRSV-W continua sendo o vírus predominante, com incidência média de 48,3\%, de um total de 614 amostras analisadas. O Zucchini yellow mosaic virus (ZYMV), o Zucchini lethal chlorosis virus (ZLCV), o Cucumber mosaic virus (CMV) e o Watermelon mosaic virus - 2 (WMV-2) foram detectados em $24,5 \%, 7,7 \%, 5,9 \%$ e 4,4\% das amostras, respectivamente (Yuki et al., 2000). Na região do Submédio São Francisco, entretanto, estudos sobre a incidência de viroses em melão (Cucumis melo L.) e melancia (Citrullus lanatus (Thunb.) Matsum. \& Nakai) mostraram que o Watermelon mosaic virus 2 (WMV-2) foi encontrado em 68,7\% das amostras analisadas, enquanto que o PRSV-W foi detectado somente em 31,2\% (Cruz et al.,1999).

O PRSV-W causa sintomas do tipo mosaico, cuja severidade depende da espécie de cucurbitácea afetada. Além do sintoma de mosaico nas folhas, as plantas doentes mostram uma redução drástica no limbo foliar e no desenvolvimento vegetativo. As perdas na produção de frutos em cultivos comerciais são variáveis, podendo, em muitos casos, chegar a $100 \%$ devido à rápida disseminação do vírus nas áreas onde ele ocorre (Greber, 1978). A redução na produção pode estar, em alguns casos, diretamente relacionada com a época de infecção das plantas (Demski \& Charkley, 1972; Herrington, 1987; Yuki et al., 1991).

O controle do mosaico causado pelo PRSV-W em cucurbitáceas tem sido investigado através do uso de casca de arroz, superfícies aluminizadas e plásticos coloridos para a 
cobertura do solo da área de plantio, com resultados experimentais satisfatórios (Moore et al., 1965; Costa \& Costa, 1971; Yuki, 1990), porém a aplicação prática é desconhecida por motivos de custo e/ou dificuldade de cobertura de áreas extensas. O controle por meio de pulverizações com inseticidas ou óleos vegetais ou minerais também tem sido testado, porém sem resultados práticos satisfatórios (Chalfant et al., 1977; Wyman et al., 1979; Yuki,1990). No caso dos inseticidas, a ineficiência deve-se ao fato de serem incapazes de matar os afideos antes da inoculação do vírus na planta. Poucos genes de resistência a vírus têm sido encontrados em germoplasma do gênero Cucurbita (Robinson \& Decker-Walters, 1997).

A premunização das plantas com estirpes fracas do vírus, que não afetam o desenvolvimento e a produção e as protegem contra a infecção e/ou manifestação de sintomas das estirpes comuns, tem se mostrado uma alternativa viável para o controle de viroses em cucurbitáceas. Esse método mostrou-se eficiente para o controle do mosaico amarelo (ZYMV) em campos experimentais de abobrinha de moita na França (Lecoq et al., 1991), em Taiwan (Wang et al., 1991) e na Inglaterra (Walkey et al., 1992), além de ser utilizado comercialmente no Hawaii (Cho et al., 1992) e em Israel (Yarden et al., 2000). A premunização também apresentou sucesso no controle do vírus do mosaico do pepino (Cucumber mosaic virus"- CMV) em melão nos Estados Unidos (Montasser et al., 1998). No Brasil, trabalhos iniciados por Rezende et al (1994) permitiram o uso comercial da premunização para o controle do mosaico causado pelo PRSV-W em abobrinha de moita (Rezende \& Pacheco, 1998) e em abóbora 'Menina Brasileira' (Rezende et al., 1999).

O presente trabalho teve por objetivo avaliar o efeito da premunização no controle do mosaico causado pelo PRSV-W em abóbora híbrida do tipo Tetsukabuto (Kabotia), através de análises de dados em casa de vegetação e em campo, devido à expansão da área de plantio desse híbrido no país, à sua sensibilidade ao mosaico e à importância econômica e social envolvida. 


\subsection{MATERIAL E MÉTODOS}

\subsubsection{Plantas-teste}

Nos testes realizados em casa de vegetação e em campo foram utilizadas plantas de abóbora híbrida [Cucurbita maxima Duch. ex Lam x C. moschata Duch. ex Poir. 'Takayama'], abobrinha-de-moita (C. pepo L. cv. Caserta) e abóbora moranga (C. maxima). Para os experimentos em campo, as mudas de abóbora híbrida foram obtidas a partir de semeadura em bandejas de isopor com 128 células, cheias com substrato à base de vermiculita, em casa de vegetação. A moranga foi semeada diretamente no campo sempre com quinze dias de antecedência para servir como polinizadora da abóbora híbrida. Plantas de 'Caserta' foram obtidas em vasos de alumínio contendo terra misturada com composto de matéria orgânica $\mathrm{e}$ adubo mineral. Foram mantidas duas plantas por vaso em casa de vegetação.

\subsubsection{Estirpes do vírus}

Duas estirpes fracas, PRSV-W-1 e PRSV-W-2 (Rezende et al., 1994), e uma comum, coletada em Campinas (PRSV-W-C), foram utilizadas nesses estudos. Essas estirpes foram mantidas em plantas de abobrinha de moita 'Caserta' em casa de vegetação.

\subsubsection{Inoculação mecânica}

A inoculação das plantas-teste foi realizada no estádio de folha cotiledonar da seguinte maneira: folhas de abobrinha de moita infectadas foram maceradas em almofariz na proporção

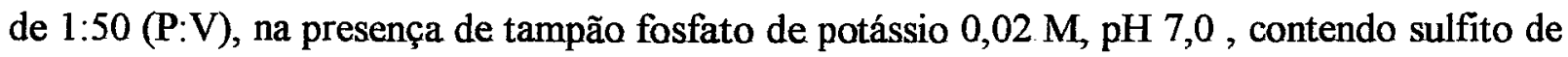
sódio $0,02 \mathrm{M}$. $\mathrm{O}$ extrato obtido foi aplicado manualmente nas folhas cotiledonares das plantasteste, previamente polvilhadas com carbureto de silício (carborundum). Em seguida, as folhas foram lavadas com água para ser removido o excesso de inóculo e de abrasivo.

\subsubsection{PTA-ELISA}

O teste sorológico de ELISA ("Enzyme Linked Immunosorbent Assay") do tipo PTA ("Plate Trapped Antigen") (Mowat \& Dawson, 1987), com algumas modificações, foi utilizado nas seguintes situaçães: a) para monitorar a premunização das plantas com as 
estirpes fracas do PRSV-W, utilizando-se antissoro policlonal específico para o vírus. Esse antissoro foi produzido na ESALQ/USP e reage inespecificamente com as estirpes fracas e comuns do PRSV-W; b) para detectar a presença de vírus contaminantes nos experimentos em campo. Nesse caso utilizaram-se antissoros contra o CMV, WMV-2, ZLCV e ZYMV. Os antissoros contra o CMV, WMV-2 e ZYMV foram produzidos na ESALQ/USP, enquanto que o antissoro contra o ZLCV foi cedido pelo Dr. A.C. de Ávila, EMBRAPA/CNPH. As leituras de absorbância foram feitas em leitor de ELISA $\Sigma 960$ (Metertech, Taiwan). Uma amostra foi considerada positiva quando o valor de absorbância foi três_vezes_superior à do_extrato-da planta sadia.

\subsubsection{Teste de recuperação das estirpes do PRSV-W}

A confirmação da infecção das plantas de abóbora híbrida com as estirpes fracas e comum foi feita, sempre que necessário, através do teste de recuperação da estirpe do vírus para plantas de abobrinha de moita, com posterior confirmação da infecção destas por PTAELISA. Extratos individualizados das plantas de abóbora 'Takayama' foram inoculados mecanicamente em folhas cotiledonares de plantas de 'Caserta', que apresentam reação diferencial para as estirpes fracas (ausência de sintomas) e comuns (mosaico severo) do PRSV-W. As observações de sintomas foram feitas periodicamente durante 25 dias após a inoculação, quando então a infecção das plantas sintomáticas e assintomáticas de 'Caserta' foi confirmada por PTA-ELISA.

\subsubsection{Testes de proteção em casa de vegetação}

Os testes de proteção de plantas de abóbora híbrida foram realizados em casa de vegetação, ESALQ/USP, comparando-se os seguintes tratamentos: A) plantas premunizadas com as estirpes fracas PRSV-W-1 e PRSV-W-2, separadamente; B) plantas premunizadas com as estirpes fracas e duplamente desafiadas mecanicamente com a estirpe PRSV-W-C, aos 15 e 25 dias após a inoculação de premunização; C) plantas inicialmente sadias, da mesma idade, e inoculadas com a estirpe PRSV-W-C aos 15 e 25 dias, separadamente, por ocasião dos desafios e D) plantas não protegidas (sadias). As plantas do tratamento " $C$ " serviram de controle do inóculo dos dois desafios e para posteriores comparações de sintomas. Todas as 
plantas foram mantidas em casa de vegetação, onde foram feitas leituras semanais de sintomas e testes de recuperação para avaliação do valor protetor das estirpes fracas. Notas de sintomas variaram de 1 (clareamento temporário de nervuras, ausência de mosaico e deformações foliares e bom desenvolvimento) a 5 (mosaico severo, deformações foliares intensas, bolhas e desenvolvimento reduzido da planta).

\subsubsection{Testes de proteção em campo}

O primeiro teste de proteção da abóbora híbrida em campo foi realizado em área experimental do Departamento de Entomologia, Fitopatologia e Zoologia Agrícola da ESALQ-USP, em Piracicaba. As mudas, obtidas em bandejas, foram inoculadas em 18/04/97 e transplantadas em campo um dia após as inoculações, em covas previamente preparadas com matéria orgânica mais adubo mineral de fórmula $4-14-8$. Foram transplantadas 3 mudas por cova. A moranga foi semeada em todo o perímetro da área experimental 15 dias antes do transplante da abóbora híbrida. Para fins de avaliação foram comparados os seguintes tratamentos: A) plantas premunizadas com a estirpe PRSV-W-1; B) plantas premunizadas com a estirpe PRSV-W-1 e desafiadas com a estirpe PRSV-W-C, 15 dias após o transplante; C) plantas inoculadas com a estirpe PRSV-W-C por ocasião da premunização e D) plantas não protegidas (sadias) expostas à infecção natural. Dez dias após o transplante foram coletadas amostras de folhas de todas as plantas inoculadas, separadamente, para confirmar as infecções com as estirpes fraca e comum do vírus, através do PTA-ELISA. Apenas uma planta, sabidamente infectada e representativa dos tratamentos, permaneceu na cova após a indexação. $O$ delineamento experimental foi o de blocos inteiramente casualizados com 4 tratamentos e 6 repetições, com espaçamento entre plantas de 3,0 × 3,0 m. Análises visuais dos sintomas de mosaico e de desenvolvimento das plantas foram feitas periodicamente. Ao final do experimento, amostras de cada planta foram coletadas e submetidas a teste de PTA-ELISA para identificar possíveis contaminações com o CMV, WMV-2, ZLCV e/ou ZYMV, e teste de recuperação das estirpes do PRSV-W para plantas de 'Caserta'. A colheita foi realizada em 03/08/97. Os frutos de cada planta foram colhidos separadamente, classificados em comerciais e não comerciais (pequenos, mal formados e/ou de coloração desuniforme) e pesados. 
O segundo teste de proteção em campo foi realizado em área de produtor comercial (Sr. Humberto Calderan, Anhembi-SP). As mudas de abóbora híbrida foram inoculadas em 19/03/99 e o transplante para o campo realizado 6 dias após as inoculações. A semeadura da moranga, o número de plantas do híbrido por cova, a indexação das plantas por PTA-ELISA e o desbaste das plantas nas covas seguiram os mesmos critérios do primeiro teste. Neste experimento foram comparados os seguintes tratamentos: A) plantas premunizadas com a estirpe PRSV-W-1; B) plantas premunizadas com a estirpe PRSV-W-2; C) plantas inoculadas com a estirpe PRSV-W-C no estádio cotiledonar e D) plantas não protegidas expostas à infecção natural. $O$ delineamento experimental foi o de blocos inteiramente casualizados com 4 tratamentos e 10 repetições, com espaçamento entre plantas de 3,0 x 3,0 m. Análises visuais de sintomas de mosaico e de desenvolvimento das plantas foram feitas periodicamente. $\mathrm{Na}$ fase intermediária de desenvolvimento das plantas, e também ao final do experimento, amostras de cada planta foram coletadas e submetidas ao teste de PTA-ELISA para identificar possíveis contaminações com o CMV, WMV-2, ZLCV e/ou ZYMV. O teste de recuperação das estirpes do PRSV-W para plantas de 'Caserta' foi realizado com amostras coletadas no final do ciclo da cultura, logo após a última colheita dos frutos. Três colheitas foram realizadas, nos dias 22/06, 05/07 e 15/07/99, respectivamente. Os frutos de cada planta foram colhidos separadamente, classificados em comerciais e não comerciais e pesados.

\subsubsection{Inoculação massal}

Para a inoculação massal da abóbora híbrida foi utilizada a estirpe PRSV-W-1, cujo inóculo foi preparado a partir de folhas infectadas de 'Caserta', trituradas em liqüidificador juntamente com tampão fosfato gelado. A diluição foi de 1:50 (g/ml). O extrato foi coado em tecido Perfex e transferido para o copo de uma pistola para pintura, juntamente com carbureto de silício $(25 \mathrm{~g} / \mathrm{L})$. O inóculo foi aplicado sob pressão, utilizando-se dois tipos de compressores, separadamente: Jet Master II, Schulz, Joinville, SC, com pressão constante de $2,8 \mathrm{kgf} \mathrm{cm}^{-2}$ e Dovat, CD 25, Joinville, $\mathrm{SC}$, com pressão ajustada para $7,0 \mathrm{kgf} \mathrm{cm}^{-2}$. A inoculação foi feita aplicando-se o inóculo nas folhas cotiledonares, mantendo-se o bico da pistola a, aproximadamente, $2 \mathrm{~cm}$ das mudas. 
Dois lotes de mudas, preparadas em bandejas, foram premunizadas em 06/10/99 e $10 / 12 / 99$, respectivamente. No primeiro lote, constituído por aproximadamente 15.000 mudas, metade das plantas foi inoculada com inóculo sob pressão de $2,8 \mathrm{kgf} \mathrm{cm}^{-2}$, enquanto o restante recebeu o inóculo sob pressão de $7,0 \mathrm{kgf} \mathrm{cm}^{-2}$. Em ambos os casos foi utilizado abrasivo adicionado ao inóculo. A pressão de inoculação para o segundo lote, de aproximadamente 17.000 mudas, foi de $7,0 \mathrm{kgf} \mathrm{cm}^{-2}$, porém metade recebeu o inóculo com o abrasivo e a outra metade sem o abrasivo. $O$ transplante das mudas em campo foi feito 3 dias após a premunização, em área de produtor comercial, em Anhembi, SP. Os campos ficaram distantes, aproximadamente, $12 \mathrm{~km}$ um do outro.

A avaliação da infecção das plantas com a estirpe PRSV-W-1 foi feita por PTAELISA e teste de recuperação para plantas de 'Caserta'. No primeiro campo foram escolhidos, ao acaso, 4 blocos com 20 plantas cada, sendo 3 blocos de mudas inoculadas com pressão de $2,8 \mathrm{kgf} \mathrm{cm}^{-2}$ e um com pressão de $7,0 \mathrm{kgf} \mathrm{cm}^{-2}$. No segundo plantio foram escolhidos, ao acaso, dois grupos de 20 plantas, representando as inoculações com e sem abrasivo. A primeira indexação das plantas foi feita 10 dias após o transplante das mudas para o campo, para avaliar a eficiência das inoculações e identificar as plantas que ainda estavam sadias. As demais indexações foram feitas aproximadamente no meio e no final do ciclo da cultura, para avaliar a possível premunização natural das plantas que não haviam sido infectadas na inoculação de premunização.

\subsubsection{Análise estatística}

Os dados de produção do primeiro e segundo experimentos de campo, respectivamente, foram analisados com o auxílio do programa ESTATÍSTICA e GLM ("General Linear Model") do sistema estatístico SAS ("Statistical Analysis System") (SAS Institute, 1990). As médias foram comparadas pelo teste de Tukey ao nível de significância de $5 \%$. 


\subsection{RESULTADOS}

\subsubsection{Proteção em casa de vegetação ${ }^{2}$}

Os resultados de dois testes independentes para avaliar o efeito protetor das estirpes fracas PRSV-W-1 e PRSV-W-2 em plantas de abóbora híbrida 'Takayama' em condições de casa de vegetação estão apresentados nas Tabelas 1 e 2 .

Quando se compararam os sintomas das plantas premunizadas e desafiadas com a estirpe comum PRSV-W-C aos 15 e 25 dias após a premunização, com os sintomas daquelas inicialmente sadias, que foram inoculadas com a mesma estirpe comum por ocasião de cada desafio, a maioria das plantas apresentou sintomas considerados fracos (notas 1 e 2). Apenas 3 plantas, entre as utilizadas como controles dos desafios, mostraram sintomas intermediários de mosaico (nota 3). Isso dificultou a avaliação da proteção com base nesse parâmetro (Tabela 1).

Tabela 1. Reação de plantas de abóbora 'Takayama' nos testes do efeito protetor de duas estirpes fracas do Papaya ringspot virus - type $W$ (PRSV-W-1 e PRSV-W-2) contra a estirpe comum de Campinas (PRSV-W-C).

\begin{tabular}{|c|c|c|c|c|c|c|}
\hline \multirow[t]{2}{*}{ Tratamentos } & \multirow[t]{2}{*}{$\begin{array}{l}\mathrm{N}^{\circ} \text { de plantas } \\
\text { Testadas }\end{array}$} & \multicolumn{5}{|c|}{$\begin{array}{c}\text { Frequiência de plantas com as } \\
\text { notas de sintomas * }\end{array}$} \\
\hline & & $1 * *$ & 2 & 3 & 4 & 5 \\
\hline PRSV-W-1 & 4 & 4 & & & & \\
\hline PRSV-W-1 + PRSV-W-C & 8 & 7 & 1 & & & \\
\hline PRSV-W-2 & 4 & 3 & & 1 & & \\
\hline PRSV-W-2 + PRSV-W-C & 8 & 6 & 2 & & & \\
\hline Sadia + PRSV-W-C aos 15 dias & 8 & 1 & 6 & 1 & & \\
\hline Sadia + PRSV-W-C aos 25 dias & 8 & 3 & 3 & 2 & & \\
\hline Sadia & 8 & 0 & 0 & 0 & 0 & 0 \\
\hline
\end{tabular}

*Avaliação feita $15-20$ dias após o 2 desafio.

${ }^{* *} 1$ = clareamento temporário de nervuras, ausência de mosaico e deformações foliares e bom desenvolvimento a $5=$ mosaico severo, deformações foliares intensas, bolhas e desenvolvimento reduzido da planta.

\footnotetext{
${ }^{2}$ Testes realizados por Rezende (1996).
} 
Os testes de recuperação das estirpes presentes nas folhas inoculadas ou desafiadas e nas folhas novas das plantas dos diferentes tratamentos, entretanto, permitiram avaliar de forma clara e segura que o efeito protetor das estirpes fracas foi positivo (Tabela 2). A maioria dos inóculos recuperados das folhas desafiadas e das folhas novas das plantas premunizadas com as estirpes PRSV-W-1 e PRSV-W-2 e desafiadas com a estirpe PRSV-W-C, não induziu sintomas perceptíveis (nota 1) em plantas de abobrinha de moita 'Caserta'. Por sua vez, todos os inóculos recuperados das folhas inoculadas e das folhas novas das plantas que serviram de controle dos inóculos dos desafios causaram sintomas extremamente severos (nota 5) em 'Caserta'.

Tabela 2. Recuperação das estirpes do Papaya ringspot virus - type $W$ presentes nas folhas (F) inoculadas e/ou desafiadas e nas folhas novas de plantas de abóbora 'Takayama', utilizadas nos testes de proteção com as estirpes fracas PRSV-W-1 e PRSV-W-2, contra a estirpe comum de Campinas (PRSV-W-C).

\begin{tabular}{|c|c|c|c|c|c|c|c|}
\hline \multirow[t]{2}{*}{ Tratamentos } & \multirow[t]{2}{*}{$\begin{array}{l}\mathrm{N}^{\circ} \text { de } \\
\text { plantas } \\
\text { testadas }\end{array}$} & \multirow[t]{2}{*}{$\begin{array}{l}\text { Origem do inóculo p/ } \\
\text { Recuperação }\end{array}$} & \multicolumn{5}{|c|}{$\begin{array}{l}N^{\circ} \text { de plantas em função dos sintomas * } \\
\text { induzidos em 'Caserta' pelos inóculos da } \\
\text { recuperação }\end{array}$} \\
\hline & & & $1 * *$ & 2 & 3 & 4 & 5 \\
\hline PRSV-W-1 & 3 & F. nova & 3 & & & & \\
\hline PRSV-W-1 + PRSV-W-C & 8 & $\begin{array}{l}\text { F. desafiada } \\
\text { F. nova }\end{array}$ & $\begin{array}{l}8 \\
8\end{array}$ & & & & \\
\hline PRSV-W-2 & 3 & F. nova & 2 & & & & 1 \\
\hline PRSV-W-2 + PRSV-W-C & 8 & $\begin{array}{l}\text { F. desafiada } \\
\text { F. nova }\end{array}$ & $\begin{array}{l}7 \\
8\end{array}$ & & & & 1 \\
\hline Sadia + PRSV-W-C & 8 & F. desafiada & & & & & 8 \\
\hline Aos 15 dias & & F. nova & & & & & 8 \\
\hline Sadia + PRSV-W-C & 8 & F. desafiada & & & & & 8 \\
\hline Aos 25 dias & & F. nova & & & & & 8 \\
\hline
\end{tabular}

* 1 = clareamento temporário de nervuras, ausência de mosaico e deformações foliares e bom desenvolvimento a $5=$ mosaico severo, deformações foliares intensas, bolhas e desenvolvimento reduzido da planta.

** Todas as plantas com nota 1 de sintoma tiveram reação positiva em PTA-ELISA com antissoro contra o PRSV-W. 


\subsubsection{Proteção em campo}

No primeiro experimento de proteção em campo, foi detectada, por PTA-ELISA, contaminação com o ZLCV em duas plantas não protegidas. Essas plantas foram desconsideradas para efeito de cálculo de média de produção e para a análise dos dados. Durante todo o ciclo da cultura, as plantas premunizadas apresentaram bom desenvolvimento, sem sintomas evidentes de mosaico e sem deformações foliares, em contraste com as plantas não protegidas, que foram naturalmente infectadas pelo complexo normal do vírus $\mathrm{e}$ mostraram sintomas acentuados da doença. Todos os inóculos recuperados das plantas naturalmente infectadas em campo induziram sintomas severos em 'Caserta'. Já os inóculos extraídos das plantas premunizadas e daquelas premunizadas e desafiadas com a estirpe PRSV-W-C não induziram sintomas perceptíveis após a recuperação em 'Caserta'. Testes de PTA-ELISA confirmaram a infeç̧ão destas pelo PRSV-W, indicando que as plantas de abóbora híbrida foram eficientemente protegidas também em campo.

A proteção das plantas refletiu na produção, como mostram os resultados da Tabela 3. A produção média (frutos/planta) das plantas premunizadas com a estirpe fraca PRSV-W-1 foi 1,3 vezes superior à das plantas premunizadas e desafiadas com a estirpe PRSV-W-C, 15 dias após a premunização, e aproximadamente 1,7 vezes superior a das plantas não protegidas que foram infectadas naturalmente com estirpes comuns do vírus. As plantas inoculadas com a estirpe PRSV-W-C no estádio cotiledonar foram as que apresentaram o menor rendimento. Comparando-se a média de produção destas, com a das plantas premunizadas (PRSV-W-1) e premunizadas/desafiadas aos 15 dias (PRSV-W-1 + PRSV-W-C), nota-se que a premunização proporcionou um aumento de 3,1 vezes na produção. Acrescenta-se que $83,7 \%$ dos frutos colhidos das plantas protegidas foram classificados como comerciais, enquanto que as infectadas com estirpes comuns produziram somente $25 \%$ de frutos dessa categoria. Ainda mais, as plantas premunizadas, além de terem produzido maior número de frutos comerciais, a produção (peso de frutos/planta) foi, aproximadamente, 2 vezes superior ao daqueles colhidos de plantas infectadas com estirpes comuns do vírus. 
Tabela 3. Número de plantas, número e pesos totais de frutos $(\mathrm{Kg})$ comerciais $(\mathrm{C})$ e não comerciais (NC) e peso médio de frutos colhidos de planta de abóbora híbrida no teste de proteção em campo. ESALQ/USP, Piracicaba.

\begin{tabular}{|c|c|c|c|c|c|c|c|c|}
\hline \multirow[t]{2}{*}{ Tratamento } & \multirow[t]{2}{*}{$\begin{array}{c}\mathrm{N}^{\mathrm{O}} \\
\text { de plantas }\end{array}$} & \multicolumn{2}{|c|}{$\begin{array}{c}\mathbf{N}^{\mathbf{o}} \\
\text { de frutos }\end{array}$} & \multicolumn{3}{|c|}{ Peso de frutos $(\mathrm{Kg})$} & \multicolumn{2}{|c|}{ Peso médio (Kg) } \\
\hline & & $\mathrm{C}$ & $\mathrm{NC}$ & $\mathbf{C}$ & $\mathrm{NC}$ & Total & Fruto & Frutos/planta \\
\hline PRSV-W-1 & 6 & 15 & 4 & 44,2 & 9,3 & 53,5 & 2,8 & 8,9 a \\
\hline PRSV-W-1 + PRSV-W-C * & 6 & 16 & 2 & 38,1 & 3,0 & 41,1 & 2,3 & $6,8 \mathrm{a}$ \\
\hline PRSV-W-C & 6 & 2 & 10 & 4,1 & 11,3 & 15,4 & 1,3 & $2,5 \mathrm{~b}$ \\
\hline Não protegida ** & 4 & 5 & 11 & 8,5 & 12,8 & 21,3 & 1,3 & $5,3 a b * * *$ \\
\hline
\end{tabular}

No segundo experimento, realizado em Anhembi-SP, a proteção da abóbora híbrida com as estirpes fracas do PRSV-W foi semelhante à obtida no primeiro teste em campo. A espécie ZYMV foi a única contaminante encontrada, por PTA-ELISA, em 3 plantas não protegidas, 2 plantas premunizadas com o PRSV-W-1, 3 plantas premunizadas com 0 PRSV-W-2 e 4 plantas inoculadas com o PRSV-W-C no estádio cotiledonar. As plantas contaminadas com esse vírus foram desconsideradas para posteriores análises dos dados. As estirpes fracas PRSV-W-1 e PRSV-W-2 protegeram 100\% das plantas premunizadas, durante o ciclo da cultura, uma vez que o teste de recuperação das estirpes presentes nessas plantas confirmou a ausência de infecção por estirpes comuns do vírus.

Na Tabela 4 é apresentada a produção total de frutos comerciais e não comerciais das plantas premunizadas e não premunizadas, bem como a produção média das mesmas. É importante mencionar que as plantas não protegidas e expostas à infecção natural tiveram dois tipos de infecção, conforme constatado pelos testes de recuperação e PTA-ELISA: 2 plantas foram infectadas com estirpes comuns do virus da região e 5 plantas foram naturalmente infectadas com uma das estirpes fracas, tornando-as premunizadas. A produção (frutos/planta) 
das plantas premunizadas com as estirpes PRSV-W-1 e PRSV-W-2 e não protegidas expostas à infecção natural foram estatisticamente semelhantes. Considerando-se apenas a produção média das 5 plantas infectadas naturalmente com as estirpes fracas $(18,9 \mathrm{Kg}$ frutos/planta), tem-se um aumento médio de $6,9 \%$, em relação à daquelas premunizadas no estádio cotiledonar. Esse pequeno acréscimo na produção dessas plantas deve-se, provavelmente, ao fato de elas terem permanecido sadias por mais tempo, antes de serem infectadas com uma das estirpes fracas do vírus. Estas, apesar de não induzirem sintomas aparentes, possivelmente devem ter um pequeno efeito no desenvolvimento e na produção das plantas, especialmente quando inoculadas em plantas no estádio cotiledonar. A média de produção (frutos/planta) das plantas premunizadas no estádio cotiledonar, juntamente com a daquelas naturalmente infectadas com a estirpe fraca, foi 2,3 vezes superior à das plantas inoculadas com a estirpe PRSV-W-C no estádio cotiledonar. Comparando-se com a produção média das 2 plantas naturalmente infectadas com as estirpes comuns do vírus em campo (14,2 $\mathrm{Kg}$ frutos/planta), verificou-se que o ganho foi de 1,3 vezes. Esse ganho é muito maior considerando-se a qualidade dos frutos, pois $97,1 \%$ da produção de todas as plantas premunizadas foi constituída por frutos comerciais, contra $2,1 \%$ de frutos dessa categoria colhidos de plantas não protegidas e naturalmente infectadas com estirpes comuns do PRSV-W (Tabela 4, Figura 1). Os frutos colhidos das plantas premunizadas, tanto no estádio cotiledonar, como naturalmente em campo, foram, aproximadamente, 1,6 vezes maiores (peso) do que os das plantas infectadas com estirpes comuns do vírus. 
Tabela 4. Número de plantas, número e pesos totais de frutos $(\mathrm{Kg})$ comerciais $(\mathrm{C})$ e não comerciais (NC) e peso médio de frutos colhidos de planta de abóbora híbrida no teste de proteção em campo. Anhembi, SP.

\begin{tabular}{|c|c|c|c|c|c|c|c|c|}
\hline \multirow[t]{2}{*}{ Tratamento } & \multirow[t]{2}{*}{$\begin{array}{c}\mathrm{N}^{\mathrm{O}} \\
\text { de plantas }\end{array}$} & \multicolumn{2}{|c|}{$\begin{array}{c}\mathrm{N}^{\circ} \\
\text { de frutos }\end{array}$} & \multicolumn{3}{|c|}{ Peso de frutos $(\mathrm{Kg})$} & \multicolumn{2}{|c|}{ Peso médio $(\mathrm{Kg})$} \\
\hline & & $\mathrm{C}$ & $\mathrm{NC}$ & $\mathrm{C}$ & $\mathrm{NC}$ & Total & Fruto & Frutos/planta \\
\hline PRSV-W-1 & 8 & 57 & 1 & 134,2 & 1,5 & 135,7 & 2,3 & $17,0 \quad a$ \\
\hline PRSV-W-2 & 7 & 49 & 5 & 119,0 & 8,6 & 127,6 & 2,4 & $18,2 \mathrm{a}$ \\
\hline PRSV-W-C & 6 & 0 & 40 & 0 & 46,8 & 46,8 & 1,2 & 7,8 b \\
\hline Não protegida* & 7 & 52 & 17 & 96,2 & 39,6 & 135,8 & 2,0 & $19,4 a^{* *}$ \\
\hline
\end{tabular}




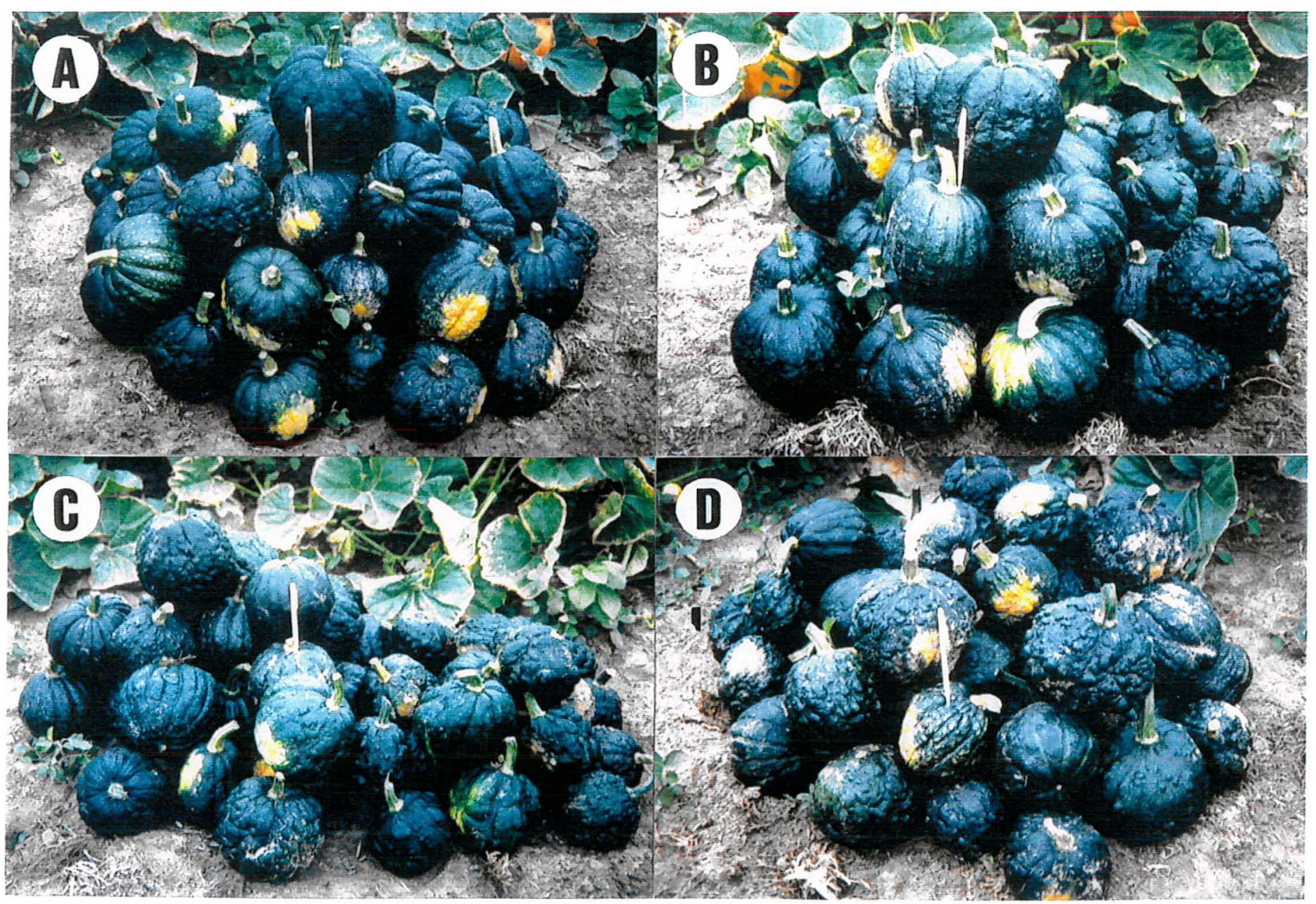

Figura 1. Frutos de abóbora híbrida, colhidos em 22/06/99, das plantas premunizadas com a estirpe PRSV-W-1 (A), premunizadas com a estirpe PRSV-W-2 (B), sadias naturalmente infectadas (C) e inoculadas com a estirpe PRSV-W-C no estádio cotiledonar (D). Anhembi, SP. 


\subsubsection{Inoculação massal}

A inoculação massal, independentemente da pressão ou da presença/ausência do abrasivo, consumiu, aproximadamente, $1 \mathrm{~L}$ de inóculo para cada 4 bandejas de mudas. Assim sendo, para a inoculação de 32.000 mudas foram necessários, aproximadamente, $60 \mathrm{~L}$ de inóculo, preparados com 1,2 kg de folhas infectadas com a estirpe PRSV-W-1. A eficiência da inoculação variou de 63\% a 79\% conforme indexação realizada com amostras das mudas, logo após o transplante em campo (Tabela 5). A maior eficiência (79\%) foi obtida quando o inóculo, misturado com o abrasivo, foi aplicado, sob pressão de $7,0 \mathrm{kgf} \mathrm{cm}^{-2}$, nas mudas do segundo plantio. Mantendo-se essa pressão, mas retirando-se o abrasivo, a eficiência de inoculação reduziu para $63 \%$. Avaliações realizadas no meio e no final do ciclo da cultura, nos dois plantios, mostraram que a maioria das plantas que permaneceram sadias foram naturalmente infectadas com a estirpe fraca em campo. Exceção para o primeiro plantio, no qual 2 plantas foram infectadas com estirpes comuns do vírus e 4 plantas permeneceram sadias. No segundo plantio, todas as plantas amostradas estavam infectadas com a estirpe fraca no final do ciclo da cultura. 
Tabela 5. Indexação de plantas de abóbora híbrida de dois plantios, cujas mudas foram inoculadas com a estirpe fraca PRSV-W-1 aplicada sob pressão, indicando a eficiência da inoculação das plantas amostradas no início do ciclo (I) e a transmissão natural da estirpe fraca para plantas avaliadas no meio $(M)$ e no final (F) do ciclo da cultura. $\mathrm{O}$ número de plantas infectadas é cumulativo.

\begin{tabular}{|c|c|c|c|c|c|c|c|c|c|}
\hline \multirow[t]{3}{*}{ Plantio } & \multirow{3}{*}{$\begin{array}{c}\text { Pressão } \\
\text { de inoculação } \\
\left(\mathrm{kgf} \mathrm{cm}^{-2}\right)\end{array}$} & \multirow{3}{*}{$\begin{array}{l}\mathbf{N}^{0} \text { plantas } \\
\text { indexadas }\end{array}$} & \multicolumn{6}{|c|}{$\mathrm{N}^{0}$ plantas infectadas } & \multirow{3}{*}{$\begin{array}{l}\mathrm{N}^{\mathrm{o}} \text { de plantas } \\
\text { sadias no final } \\
\text { do ciclo }\end{array}$} \\
\hline & & & \multicolumn{3}{|c|}{ Estirpe fraca } & \multicolumn{3}{|c|}{ Estirpe comum } & \\
\hline & & & I & $\mathbf{M}$ & F & I & $\mathbf{M}$ & $\mathbf{F}$ & \\
\hline $\mathrm{I}$ & $2,8 \mathrm{c} /$ abrasivo & 48 & 35 & 37 & 43 & 0 & 2 & 2 & 3 \\
\hline I & $7,0 \mathrm{c} /$ abrasivo & 15 & 10 & 11 & 14 & 0 & 0 & 0 & 1 \\
\hline II & $7,0 \mathrm{c} /$ abrasivo & 19 & 15 & 18 & 19 & 0 & 0 & 0 & 0 \\
\hline II & $7,0 \mathrm{~s} /$ abrasivo & 19 & 12 & 17 & 19 & 0 & 0 & 0 & 0 \\
\hline
\end{tabular}

\subsection{DISCUSSÃO}

Neste trabalho demonstrou-se que as estirpes fracas PRSV-W-1 e PRSV-W-2 protegeram eficientemente plantas de abóbora híbrida 'Takayama' contra a infecção com a estirpe comum de Campinas (PRSV-W-C), em testes em casa de vegetação. Essa afirmativa baseia-se principlamente nos resultados dos testes de recuperação, que indicaram a ausência da estirpe PRSV-W-C, tanto nas folhas desafiadas como nas folhas novas da maioria das plantas previamente inoculadas com as estipes fracas. Exceção para um inóculo obtido de uma folha desafiada de uma planta premunizada com a estirpe PRSV-W-2, que causou sintomas severos em 'Caserta' (nota 5) (Tabela 2). Como o inóculo recuperado das folhas novas dessa mesma planta causou sintomas fracos em 'Caserta', sugere-se que, neste caso, a estirpe desafiante foi capaz de multiplicar na folha inoculada (desafiada), porém impedida de invadir a planta sistemicamente. Uma outra exceção ocorreu com um inóculo recuperado de folhas novas de uma planta que estava apenas premunizada com a estirpe fraca PRSV-W-2 e que também provocou sintomas severos em abobrinha de moita (Tabela 2). É importante salientar que a planta doadora desse inóculo é a mesma que já vinha apresentando sintomas 
intermediários de mosaico (nota 3 ) durante as avaliações (Tabela 1). Como essa planta não foi desafiada com a estirpe PRSV-W-C, sugere-se que a intensificação dos sintomas estava associada a uma possível reversão da estirpe fraca, para formas semelhantes às do complexo normal do vírus. Problema dessa natureza, associado com a estirpe PRSV-W-2, foi relatado por Rezende \& Pacheco (1997). Resultados semelhantes de proteção com as estirpes fracas PRSV-W-1 e PRSV-W-2 foram obtidos em plantas premunizadas de abobrinha de moita (Rezende \& Pacheco, 1998) e de abóbora rasteira 'Menina Brasileira' (Rezende et al., 1999), em experimentos em casa de vegetação.

As estirpes fracas do PRSV-W também foram eficientes para a proteção de plantas da abóbora hibrida 'Takayama' em condições de campo. Nos dois testes, verificou-se que no final do ciclo da cultura, $100 \%$ das plantas premunizadas estavam infectadas apenas com as estirpes fracas previamente inoculadas, pois em nenhum caso foi possível recuperar estirpes comuns do vírus a partir de inóculos extraídos dessas plantas. Além de proteger as plantas contra a infecção e/ou manifestação das estirpes comuns do vírus, a premunização permitiu um aumento significativo na produção, tanto quantitativo (Tabelas 3 e 4), como qualitativo (Figura 1). Comparando-se a produção das plantas dos dois experimentos em campo nota-se que a do segundo foi bem superior à do primeiro. Essa diferença possivelmente deve-se ao fato de que o primeiro teste foi realizado em pequena área experimental do Departamento de Entomologia, Fitopatologia e Zoologia Agrícola da ESALQ/USP, enquanto que o segundo foi feito em área onde normalmente o agricultor cultiva plantas dessa espécie, com todos os cuidados necessários para se obter o maior rendimento possível.

Esses resultados corroboram os obtidos por Rezende \& Pacheco, (1998) e Rezende et al. (1999) em testes de proteçãa de abobrinha de moita e de abóbora rasteira 'Menina Brasileira' em condições de campo. Plantas de abobrinha de moita 'Caserta' premunizadas com as estirpes PRSV-W-1 e PRSV-W-2 tiveram aumento na produção de frutos comerciais da ordem de $633 \%$ e de $344 \%$, no primeiro e no segundo experimento, respectivamente. No caso da abóbora 'Menina Brasileira', que é tolerante ao mosaico causado pelo PRSV-W, a premunização, além do efeito aditivo no controle da doença em campo, proporcionou ganho médio de $33 \%$ na produção de frutos comerciais, em relação às plantas infectadas naturalmente com estirpes comuns do vírus. 
Desde que a premunização de cucurbitáceas foi proposta por Lecoq et al. (1991) para o controle do mosaico amarelo da abobrinha (ZYMV) na França, estudos para a aplicação dessa técnica para o controle desta e de outras viroses que afetam plantas dessa familia foram realizados com sucesso em outros países. Em Taiwan, Wang et al. (1991) mostraram que a estirpe fraca ZYMV-WK, selecionada por Lecoq et al. (1991), controlou a doença em campos de abobrinha, com ganhos na produção da ordem de $116 \%$ e 1256\%, no primeiro e no segundo ano, respectivamente. Walkey et al. (1992), na Inglaterra, também relataram resultados positivos no controle do mosaico amarelo da abobrinha por premunização, com ganhos significativos na produção de frutos comerciais. Perring et al. (1995) mostraram resultados positivos de proteção em plantas de melão na Califórnia, EUA. Mais recentemente, Montasser et al. (1998) observaram que plantas de melão premunizadas com uma estirpe fraca do CMV, em associação com um RNA satélite que atenua os sintomas do CMV, ficaram protegidas contra a infecção por estirpes severas do vírus, em testes em casa de vegetação e em campo, no Estado de Maryland, EUA. Avaliaçães de produção em campo revelaram que as plantas premunizadas tiveram produção semelhante à de plantas sadias, porém $53 \%$ superior à daquelas não premunizadas e que foram infectadas pela estirpe comum do CMV. Essa tecnologia já vem sendo empregada comercialmente no Japão na produção de mudas premunizadas de pimentão, de acordo com Kaper ${ }^{3}$.

O sucesso da proteção da abóbora híbrida do tipo Tetsukabuto, associado com a estabilidade das estirpes fracas do PRSV-W, permitem recomendar a premunização também para o controle do mosaico em plantas desse híbrido. A aplicação dessa tecnologia, entretanto, depende de um sistema eficiente de inoculação massal de mudas, semelhante ao estabelecido por Rezende e Pacheco (1998) para a premunização de mudas de abobrinha de moita. Naquele trabalho os autores verificaram que inóculos diluídos entre 1:50 e 1:200, e aplicados sob pressão de $2,8 \mathrm{kgf} \mathrm{cm}^{-2}$, com uma pistola para pintura, causaram infecção em $100 \%$ das mudas de abobrinha de moita. No caso das mudas de abóbora 'Takayama', a aplicação desse método, com algumas variações, mostrou que a eficiência de inoculação variou de $63 \%$ a $79 \%$. É possível que a menor porcentagem de plantas infectadas da abóbora híbrida, mesmo quando a pressão de inoculação foi de $7,0 \mathrm{kgf} \mathrm{cm}^{-2}$, se deve ao fato de as folhas cotiledonares dessas

\footnotetext{
${ }^{3}$ Kaper J.M. (Plant Science Institute, USDA, Beltsville, USA). Comunicação pessoal, 1999.
} 
plantas serem um pouco mais rígidas do que as da abobrinha de moita. Apesar de a inoculação de premunização ter atingido, em média, aproximadamente $75 \%$ das mudas, esse fato não parece ter prejudicado o controle do mosaico, pois a maioria das plantas que permaneceram sadias foram naturalmente infectadas com a estirpe fraca, através da ação dos afideos vetores, durante o ciclo de desenvolvimento da cultura, tornando-as premunizadas (Tabela 5). Esse fato, associado com a indicação experimental de que as plantas premunizadas em idade mais avançada têm a tendência de apresentar produção ligeiramente superior à daquelas inoculadas no estádio cotiledonar (Tabela 4), permitem pensar que a premunização natural de parte das plantas em campo poderá ser benéfica, aumentando a produtividade. Estudos para melhor avaliar essa hipótese devem ser realizados com diferentes porcentagens de plantas premunizadas e sadias plantadas em mistura.

A premunização é uma alternativa de controle biológico que apresenta diversas vantagens no controle de fitoviroses. Não polui, não apresenta riscos para os agricultores e consumidores, não interfere com outras práticas culturais, é de simples aplicação e de baixo custo. Apesar dessas vantagens, alguns autores (Fulton, 1986; Posnette \& Todd, 1955) apontam que a premunização de grande número de plantas com estirpes fracas de um vírus pode representar alguns riscos. Entre eles estão, principlamente, o possível efeito sinergístico entre a estirpe fraca premunizante e outros vírus que possam infectar a espécie premunizada, a quebra de proteção, a possibilidade de a estirpe fraca causar doença de importância econômica em outra espécie vegetal e a reversão da estirpe fraca para formas comuns do vírus. A reversão de sintomas, aparentemente associada com mutação, foi relatada por Rezende \& Pacheco (1997) para a estirpe PRSV-W-2. Observações mais recentes, entretanto, têm mostrado que tanto esta, como a estirpe PRSV-W-1, têm se mantido aparentemente estáveis nos últimos anos (dados não publicados). Além disso, Rezende e Müller (1995) acreditam que os riscos apontados não devem ser utilizados como argumentos para impedir a aplicação dessa alternativa de controle. No caso presente, face à sensibilidade das plantas de abóbora hibrida do tipo Tetsukabuto ao mosaico causado pelo PRSV-W, recomenda-se a premunização, até que híbridos resistentes ou tolerantes, obtidos pelo melhoramento genético convencional ou transgênico, estejam disponíveis aos agricultores. 


\subsection{CONCLUSÕES}

1- As estirpes fracas PRSV-W-1 e PRSV-W-2 protegeram plantas de abóbora híbrida do tipo Tetsukabuto contra a infecção com a estirpe comum de Campinas, em testes em casa de vegetação.

2- As estirpes fracas PRSV-W-1 e PRSV-W-2 também protegeram plantas de Tetsukabuto em campo, proporcionando ganhos significativos na produção.

3- A maior eficiência de inoculação massal de mudas de aboboreira híbrida do tipo Tetsukabuto (79\%) foi alcançada aplicando-se o inóculo, juntamente com carborundum, sob pressão de $7,0 \mathrm{Kgf} \mathrm{cm}^{-2}$.

\section{PROBlemas NA PREMUNIZAÇÃo de MELANCIA PARA O CONTROLE dO MOSAICO CAUSADO PELO Papaya ringspot virus - type $W$ (PRSV-W)}

\section{RESUMO}

Neste trabalho, estudou-se a premunização de melancia com estirpes fracas do Papaya ringspot virus - type $W$ (PRSV-W-1 e PRSV-W-2) em condições de casa de vegetação e em campo. Os resultados mostraram que a estirpe PRSV-W-1 protegeu as plantas contra as estirpes comuns PRSV-W-C, PRSV-W-B e PRSV-W-P, separadamente, em testes em casa de vegetação. Nos experimentos em campo, compararam-se o desenvolvimento e a produção de plantas de melancia dos cultivares Crimson Sweet e Crimson Tide premunizadas com as estirpes PRSV-W-1 e PRSV-W-2, não premunizadas expostas à infecção natural e inoculadas com a estirpe comum PRSV-W-C no estádio cotiledonar. A proteção também foi eficiente em condições de campo, porém, as plantas protegidas do cultivar Crimson Sweet tiveram uma redução no peso médio de frutos por planta de, aproximadamente, 2,4 e 1,2 vezes, em comparação às plantas não protegidas que estavam sadias, no primeiro e no segundo teste, respectivamente. $\mathrm{O}$ mesmo fato ocorreu com o cultivar Crimson Tide, no qual registrou-se uma redução de 1,7 vezes, aproximadamente, em um único teste. Além da

redução na produção, outro problema encontrado na premunização da melancia foi a 
necessidade de duas inoculações sucessivas das mudas, em dias consecutivos, para aumentar a freqüência de plantas protegidas. Apesar desses problemas, acredita-se que a premunização da melancia com essas estirpes fracas possa ser valiosa nas regiões e/ou épocas de alta incidência do PRSV-W. Estudos estão sendo desenvolvidos na tentativa de encontrar estirpes fracas do vírus que infectem mais facilmente as mudas de melancia e que não causem perdas tão acentuadas na produção.

\section{SUMMARY}

Studies were carried out to evaluate the protective effect of two mild strains of Papaya ringspot virus - type $W$ (PRSV-W-1 and PRSV-W-2) on watermelon plants under greenhouse and field conditions. The results showed that the mild strain PRSV-W-1 protected watermelon plants against the effects of three common strains (PRSV-W-C, PRSV-W-B and PRSV-W-P), separately, in greenhouse tests. Two field tests with protected and unprotected plants of watermelon cvs. Crimson Sweet and Crimson Tide also showed protective effect of both mild strains. However, protected plants of 'Crimson Sweet' showed a reduction on the average weight of fruit per plant of, aproximately, 2.4 and 1.2 times, as compared to the yield of healthy plants, in the first and second trials, respectively. Yield reduction on protected 'Crimson Tide' was aproximately 1.7 times in one trial. In addition to yield reduction, another problem of cross protection on watermelon was the requirement of two successive inoculations of the seedling, on consecutive days, to increase the frequence of protected plants. In spite of these problems, cross protection may be valuable for watermelon in those regions and/or season with high incidence of PRSV-W. Studies are under way in order to select mild strains of PRSV-W that are more infective on watermelon and do not cause significant yield reduction.

\subsection{INTRODUÇÃO}

Na família Cucurbitaceae, a melancia [Citrullus lanatus (Thunb.) Matsum \& Nakai], originária da África, apresenta-se como importante hortaliça cultivada em diversos países 
como China, África, Índia, EUA (Robinson \& Decker-Walters, 1997) e Brasil. O volume comercializado de melancia na CEAGESP em São Paulo, no ano de 1998, foi de aproximadamente $60.500 \mathrm{t}$, com aumento crescente desde 1995, apesar da queda em preço do produto no decorrer desses últimos anos (FNP, 2000). Em 1999, no estado de São Paulo, a área cultivada de melancia foi registrada em 9.283 ha (Instituto de Economia Agrícola - IEA e Coordenadoria de Assistência Técnica Integral - CATI).

O Papaya ringspot virus - type W (PRSV-W) é um Potyvirus transmitido de maneira não persistente por diversas espécies de afídeos e que afeta cucurbitáceas em geral, inclusive a melancia, em diversos estados brasileiros. Em São Paulo, estudos recentes desenvolvidos por Yuki et al. (2000), sobre a incidência de viroses em cucurbitáceas, revelaram que o PRSV-W é o vírus de maior incidência no Estado, seguido pelo Zucchini yellow mosaic virus (ZYMV) e Zucchini lethal chlorosis virus (ZLCV).

Plantas de melancia infectadas com o PRSV-W geralmente exibem mosaico e deformidades foliares, redução no limbo foliar e no desenvolvimento vegetativo e prejuízos na produção, devido à redução no número e no tamanho dos frutos. Na região do Submédio São Francisco, que se destaca como importante produtora de melancia no Brasil, já foram observados danos de $100 \%$ em lotes de projetos de irrigação, com base em Lima ${ }^{4}$.

Devido à ausência de cultivares e híbridos comerciais resistentes ao vírus, à baixa eficiência do controle químico dos afídeos vetores e à dificuldade da utilização prática de métodos físicos e culturais que minimizem a disseminação do vírus nos plantios (Moore et al., 1965; Costa \& Costa, 1971; Chalfant et al., 1977; Wyman et alii, 1979; Yuki, 1990), o controle do mosaico em melancia exige investigações de métodos alternativos. $\mathrm{O}$ uso da premunização no Brasil, na qual plantas em estádio cotiledonar são inoculadas com estirpe fraca protetora do PRSV-W, já foi avaliada em abobrinha de moita (Cucurbita pepo L.), abóbora rasteira (C. moschata (Duch. ex Lam) Duch ex Poir cv. Menina Brasileira) (Rezende \& Pacheco, 1998; Rezende et al, 1999) e em abóbora híbrida (C. maxima Duch. ex Lam x C moschata) do tipo Tetsukabuto, com resultados satisfatórios no controle da doença, acompanhado por ganhos na produção (Capítulo 3). Além dos resultados experimentais

\footnotetext{
${ }^{4}$ Lima, M.F. (EMBRAPA Semi-Árido, Petrolina). Comunicação pessoal, 1998.
} 
satisfatórios, a premunização de abobrinha de moita e de abóboras já vem sendo empregada comercialmente desde meados de 1997. Somente no Estado de São Paulo, estima-se que perto de 1 milhão de mudas já tenham sido premunizadas com a estirpe PRSV-W-1. Diante desse fato, o presente trabalho teve por objetivo avaliar o efeito das estirpes fracas do PRSV-W no controle do mosaico causado pelas estirpes comuns desse vírus em melancia.

\subsection{MATERIAL E MÉTODOS}

\subsubsection{Plantas-teste}

Dois cultivares de melancia, Charleston Gray e Crimson Sweet, e a abobrinha de moita cv. Caserta foram utilizados em testes em casa de vegetação. Em campo, foram usados os cultivares Crimson Sweet e Crimson Tide, cujas mudas foram obtidas em bandejas de isopor com 128 células.

\subsubsection{Estirpes do vírus}

Duas estirpes fracas, PRSV-W-1 e PRSV-W-2 (Rezende et al., 1994), e três estirpes comuns, coletadas em Campinas (PRSV-W-C), Botucatu (PRSV-W-B) e Petrolina (PRSV-W$P)$, foram utilizadas nesses estudos. As estirpes foram mantidas, separadamente, em abobrinha de moita em casa de vegetação.

\subsubsection{Inoculação mecânica}

A inoculação das plantas-teste foi realizada no estádio de folha cotiledonar da seguinte maneira: folhas de abobrinha de moita infectadas com as estirpes do vírus, separadamente, foram maceradas em almofariz, na presença de tampão de fosfato de potássio $0,02 \mathrm{M}, \mathrm{pH}$ 7,0, contendo sulfito de sódio $0,02 \mathrm{M}$, na proporção de 1:50 (P/V). O extrato obtido foi inoculado mecanicamente em folhas cotiledonares das plantas-teste, previamente polvilhadas com carborundum. Em seguida, as folhas foram lavadas com água para remover o excesso de inóculo e de abrasivo. 


\subsubsection{PTA-ELISA}

O teste sorológico de ELISA ("Enzyme Linked Immunosorbent Assay") do tipo PTA ("Plate Trapped Antigen") (Mowat \& Dawson, 1987), com algumas modificações, foi utilizado nas seguintes situaçães: a) para monitorar a premunização das plantas inoculadas com as estirpes fracas do PRSV-W, utilizando-se antissoro policlonal específico para o vírus e b) para detectar a presença de vírus contaminantes nos experimentos em campo. Neste caso, utilizaram-se antissoros contra o CMV, WMV-2, ZLCV e ZYMV. As leituras de absorbância foram feitas em leitor de ELISA $\Sigma 960$ (Metertech, Taiwan). Uma amostra foi considerada positiva quando o valor de absorbância foi três vezes superior à absorbância do extrato da planta sadia.

\subsubsection{Teste de recuperação das estirpes do PRSV-W}

A confirmação da infecção das plantas de melancia com as estirpes fracas e comuns foi feita, sempre que necessário, através do teste de recuperação da estirpe do vírus para plantas de abobrinha de moita, com posterior confirmação da infecção destas por PTAELISA. Extratos individualizados das plantas de melancia foram inoculados mecanicamente em folhas cotiledonares de abobrinha de moita 'Caserta', que apresentam reação diferencial para as estirpes fracas e fortes do PRSV-W. As observações de sintomas foram feitas periodicamente, até a confirmação da infecção por PTA-ELISA.

\subsubsection{Testes de proteção em casa de vegetação}

Testes de proteção de plantas de melancia, em casa de vegetação, foram realizados no Departamento de Entomologia, Fitopatologia e Zoologia Agrícola, ESALQ/USP, utilizandose os cultivares Charleston Gray e Crimson Sweet. Foram comparados os seguintes tratamentos: A) plantas premunizadas com a estirpe fraca PRSV-W-1; B) plantas premunizadas com a estirpe PRSV-W-1 e duplamente desafiadas mecanicamente com as estirpes PRSV-W-C, PRSV-W-B e PRSV-W-P, separadamente. As inoculações de desafio foram feitas aos 15 e 25 dias após inoculação de premunização; C) plantas inicialmente sadias, da mesma idade, inoculadas com as estirpes comuns, separadamente, por ocasião de cada desafio e D) plantas sadias. As plantas do tratamento "C" serviram de controle dos 
inóculos dos 2 desafios e para posteriores comparações de sintomas. Todas as plantas foram mantidas em casa de vegetação, onde foram feitas leituras semanais de sintomas e testes de recuperação para avaliação do valor protetor das estirpes fracas. Notas de sintomas variaram de 1 (mosaico pouco evidente, sem deformações foliares e bom desenvolvimento) a 5 (mosaico severo, deformações foliares intensas, bolhas e desenvolvimento reduzido da planta).

\subsubsection{Testes de proteção em campo}

Dois testes de proteção em campo foram realizados em área do Sr. Humberto Calderan, em Anhembi-SP. O primeiro foi conduzido com o cultivar Crimson Sweet. As mudas foram inoculadas em 01/07/97 e o transplante em campo realizado três dias depois. Os tratamentos constaram de: A) plantas premunizadas com a estirpe PRSV-W-1; B) plantas premunizadas com a estirpe PRSV-W-2; C) plantas premunizadas com a estirpe PRSV-W-1 e desafiadas com a estirpe PRSV-W-C; D) plantas premunizadas com a estirpe PRSV-W-2 e desafiadas com a estirpe PRSV-W-C; E) plantas inoculadas com a estirpe PRSV-W-C no estádio cotiledonar e F) plantas não protegidas (sadias) expostas à infecção natural. Os desafios (tratamentos $\mathrm{C}$ e D) foram realizados, aproximadamente, 10 dias após o transplante das mudas em campo. A proteção das plantas de melancia foi avaliada através de observações periódicas de sintomas e, principalmente, por meio de teste de recuperação das estirpes presentes nas mesmas para plantas de 'Caserta', no final do experimento. A colheita foi realizada em 22/10/97. No segundo experimento foram utilizados dois cultivares: Crimson Sweet e Crimson Tide. As mudas foram inoculadas em 13/08/99 e transplantadas em 18/08/99. Os tratamentos foram: A) plantas premunizadas com a estirpe PRSV-W-1; B) plantas premunizadas com a estirpe PRSV-W-2; C) plantas inoculadas com a estirpe PRSV-W-C no estádio cotiledonar e D) plantas não protegidas (sadias) expostas à infecção natural. No meio e ao final do ciclo da cultura, amostras de todas as plantas foram coletadas individualmente e avaliadas para a identificação de possíveis contaminações com o CMV, WMV-2, ZLCV e/ou ZYMV. Avaliações de produção foram feitas da mesma maneira do primeiro teste em campo. Duas colheitas foram realizadas, em 23/11/99 e 04/01/2000. 
Nos dois experimentos foram plantadas 3 mudas por cova, duplamente inoculadas. Quinze dias após o plantio, foram coletadas amostras de folhas de todas as plantas inoculadas, separadamente, para confirmar as infecções com as estirpes fracas e comum do vírus, através do PTA-ELISA. Apenas uma planta, sabidamente infectada e representativa dos tratamentos, permaneceu na cova após a indexação. $O$ delineamento experimental foi $o$ de blocos inteiramente casualizados com 6 tratamentos e 10 repetições para o primeiro teste e 4 tratamentos e 10 repetições para o segundo. $O$ espaçamento entre plantas foi de 3,0 x 3,0 m. Cada planta representou uma parcela.

\subsubsection{Análise estatística}

Os dados de produção dos experimentos foram analisados com o auxílio do programa GLM ("General Linear Model") do sistema estatístico SAS ("Statistical Analysis System") (SAS Institute, 1990). As médias foram comparadas pelo teste de Tukey ao nível de significância de $5 \%$.

\subsection{RESULTADOS}

\subsubsection{Proteção em casa de vegetação}

Testes iniciais em casa de vegetação, submetendo as plântulas de melancia, em estádio cotiledonar, a apenas uma inoculação de premunização, revelaram uma baixa eficiência de infecção. Já para as três estirpes comuns (PRSV-W-C, PRSV-W-B e PRSV-W-P), separadamente, apenas uma inoculação mecânica foi suficiente para causar a infecção de $100 \%$ das plantas. Na tentativa de aumentar o número de plantas infectadas com a estirpe fraca, optou-se por uma dupla inoculação mecânica em dias consecutivos. Com isso, o número de plantas premunizadas atingiu $80 \%$, aproximadamente. Esse critério de inoculação foi adotado em todos os testes de casa de vegetação e em campo.

De maneira geral, verificou-se que a maioria das plantas dos cultivares Charleston Gray e Crimson Sweet, inoculadas com a estirpe PRSV-W-1 e desafiadas com as estirpes comuns, apresentaram desenvolvimento semelhante ao daquelas sadias, com sintomas imperceptíveis de mosaico. Exceto 3 plantas de 'Charleston Gray' premunizadas e desafiadas 
com a estirpe comum PRSV-W-B e 2 plantas premunizadas e desafiadas com a estirpe PRSV-W-P, que apresentaram sintomas intermediários (grau 3) de mosaico (Tabela 1). Inóculos extraídos da maioria dessas plantas causaram sintomas severos em 'Caserta', indicando a presença da estirpe comum do vírus (Tabela 2). A proteção, nas outras plantas, foi confirmada por meio do teste de recuperação, juntamente com o teste de PTA-ELISA. Estes, confirmaram que a maioria das plantas de melancia premunizadas e desafiadas, e que apresentavam sintomas imperceptíveis de mosaico, estavam somente infectadas com a estirpe fraca PRSV-W-1. No caso do cultivar 'Crimson Sweet', todas as plantas premunizadas e desafiadas com as 3 estirpes comuns apresentaram sintomas fracos ou imperceptiveis de mosaico (Tabela 3). No entanto, os testes de recuperação indicaram a presença de estirpes comuns do vírus em 2 plantas premunizadas e desafiadas com a estirpe PRSV-W-B e em 8 plantas premunizadas e desafiadas com a estirpe PRSV-W-P (Tabela 4). As demais plantas premunizadas e desafiadas eram portadoras apenas da estirpe fraca. Todas as plantas de melancia, de ambos os cultivares, premunizadas com a estirpe PRSV-W-1 e não desafiadas com as estirpes comuns apresentaram apenas sintomas pouco evidentes de mosaico (grau 1). Por outro lado, a maioria das plantas não protegidas, que foram inoculadas com as estirpes comuns, tiveram o desenvolvimento afetado e apresentaram sintomas severos (graus 4 e 5). 
Tabela 1. Reação de plantas de melancia 'Charleston Gray' nos testes do efeito protetor de uma estirpe fraca do Papaya ringspot virus - type $W$ (PRSV-W-1) contra as estirpes comuns do virus de Campinas (PRSV-W-C), Botucatu (PRSV-W-B) e Petrolina (PRSV-W-P).

\begin{tabular}{|c|c|c|c|c|c|c|}
\hline \multirow[t]{2}{*}{ Tratamentos } & \multirow[t]{2}{*}{$\begin{array}{l}\mathrm{N}^{\mathbf{0}} \text { de plantas } \\
\text { testadas }\end{array}$} & \multicolumn{5}{|c|}{$\begin{array}{c}\text { Freqüência de plantas com as } \\
\text { notas de sintomas ** }\end{array}$} \\
\hline & & 1 & 2 & 3 & 4 & 5 \\
\hline PRSV-W-1 & 4 & 4 & & & & \\
\hline PRSV-W-1 + PRSV-W-C & 12 & 12 & & & & \\
\hline Sadia + PRSV-W-C aos 15 dias & 4 & & 2 & & & 2 \\
\hline Sadia + PRSV-W-C aos 25 dias & 4 & & 2 & & 2 & \\
\hline PRSV-W-1 & 6 & 6 & & & & \\
\hline PRSV-W-1 + PRSV-W-B & 16 & 13 & & 3 & & \\
\hline Sadia + PRSV-W-B aos 15 dias & 6 & & 2 & & 2 & 2 \\
\hline Sadia + PRSV-W-B aos 25 dias & 6 & 4 & & & & 2 \\
\hline PRSV-W-1 & 6 & 5 & & 1 & & \\
\hline PRSV-W-1 + PRSV-W-P & 18 & 16 & & 2 & & \\
\hline Sadia + PRSV-W-P aos 15 dias & 6 & & 2 & 2 & 2 & \\
\hline Sadia + PRSV-W-P aos 25 dias & 6 & & & 4 & 2 & \\
\hline
\end{tabular}

*Resultados de dois testes independentes.

**1 = mosaico pouco evidente, sem deformações foliares e bom desenvolvimento.

$5=$ mosaico severo, deformações foliares intensas, bolhas e desenvolvimento reduzido da planta. 
Tabela 2. Recuperação das estirpes do Papaya ringspot virus - type W (PRSV-W) presentes nas folhas (F) inoculadas e/ou desafiadas e nas folhas novas de plantas de melancia 'Charleston Gray', utilizadas nos testes de proteção com a estirpe fraca PRSV-W-1, contra as estirpes comuns de Campinas (PRSV-W-C), Botucatu (PRSV-W-B) e Petrolina (PRSV-W-P).

\begin{tabular}{|c|c|c|c|c|c|c|c|}
\hline \multirow[t]{2}{*}{ Tratamentos } & \multirow[t]{2}{*}{$\begin{array}{c}\mathrm{N}^{\mathbf{0}} \\
\text { de plantas } \\
\text { testadas }\end{array}$} & \multirow[t]{2}{*}{$\begin{array}{l}\text { Origem do inóculo } \\
\text { p/ recuperação }\end{array}$} & \multicolumn{5}{|c|}{$\begin{array}{l}\mathrm{N}^{\circ} \text { de plantas em função dos sintomas* } \\
\text { induzidos em 'Caserta' pelos inóculos da } \\
\text { recuperação }\end{array}$} \\
\hline & & & $1 * *$ & 2 & 3 & 4 & 5 \\
\hline PRSV-W-1 & 4 & F. nova & 4 & & & & \\
\hline PRSV-W-1 + PRSV-W-C & 12 & $\begin{array}{l}\text { F. desafiada } \\
\text { F. nova }\end{array}$ & $\begin{array}{l}12 \\
11\end{array}$ & 1 & & & \\
\hline $\begin{array}{l}\text { Sadia + PRSV-W-C } \\
\text { aos } 15 \text { dias }\end{array}$ & 4 & $\begin{array}{l}\text { F. desafiada } \\
\text { F. nova }\end{array}$ & & & & & $\begin{array}{l}4 \\
4\end{array}$ \\
\hline $\begin{array}{l}\text { Sadia + PRSV-W-C } \\
\text { aos } 25 \text { dias }\end{array}$ & 4 & $\begin{array}{l}\text { F. desafiada } \\
\text { F. nova }\end{array}$ & & & & & $\stackrel{4}{\text { NT }} * * *$ \\
\hline PRSV-W-1 & 6 & F. nova & 6 & & & & \\
\hline PRSV-W-1 + PRSV-W-B & 16 & $\begin{array}{l}\text { F. desafiada } \\
\text { F. nova }\end{array}$ & $\begin{array}{l}14 \\
13\end{array}$ & 1 & & & $\begin{array}{l}2 \\
2\end{array}$ \\
\hline $\begin{array}{l}\text { Sadia + PRSV-W-B } \\
\text { aos } 15 \text { dias }\end{array}$ & 6 & $\begin{array}{l}\text { F. desafiada } \\
\text { F. nova }\end{array}$ & & & & 4 & $\begin{array}{l}2 \\
6\end{array}$ \\
\hline $\begin{array}{l}\text { Sadia + PRSV-W-B } \\
\text { aos } 25 \text { dias }\end{array}$ & 6 & $\begin{array}{l}\text { F. desafiada } \\
\text { F. nova }\end{array}$ & $\begin{array}{l}4 \\
4\end{array}$ & & & & $\begin{array}{l}2 \\
2\end{array}$ \\
\hline PRSV-W-1 & 6 & F. nova & 6 & & & & \\
\hline PRSV-W-1 + PRSV-W-P & 18 & $\begin{array}{l}\text { F. desafiada } \\
\text { F. nova }\end{array}$ & $\begin{array}{l}14 \\
14\end{array}$ & $\begin{array}{l}1 \\
1\end{array}$ & & & $\begin{array}{l}3 \\
3\end{array}$ \\
\hline $\begin{array}{l}\text { Sadia + PRSV-W-P } \\
\text { aos } 15 \text { dias }\end{array}$ & 6 & $\begin{array}{l}\text { F. desafiada } \\
\text { F. nova }\end{array}$ & & & & & $\begin{array}{l}6 \\
6\end{array}$ \\
\hline $\begin{array}{l}\text { Sadia + PRSV-W-P } \\
\text { aos } 25 \text { dias }\end{array}$ & 6 & $\begin{array}{l}\text { F. desafiada } \\
\text { F. nova } \\
\end{array}$ & 2 & & & & $\begin{array}{l}4 \\
6 \\
\end{array}$ \\
\hline $\begin{array}{l}* 1=\text { clareamento tempo } \\
\text { desenvolvimento a } 5= \\
\text { reduzido da planta. } \\
* * \text { Todas as plantas com r } \\
\text { contra o PRSV-W. } \\
* * * \text { Não testada }\end{array}$ & $\begin{array}{l}\text { orário de } \mathrm{r} \\
\text { mosaico } \mathrm{s} \\
\text { nota } 1 \mathrm{de}\end{array}$ & $\begin{array}{l}\text { as, ausência de } \\
\text { deformações fo } \\
\text { a tiveram reaçã }\end{array}$ & inte & & & & $\begin{array}{l}\text { mo } \\
\text { to }\end{array}$ \\
\hline
\end{tabular}


Tabela 3. Reação de plantas de melancia 'Crimson Sweet' nos testes do efeito protetor de uma estirpe fraca do Papaya ringspot virus - type W (PRSV-W-1) contra as estirpes comuns do virus de Campinas (PRSV-W-C), Botucatu (PRSV-W-B) e Petrolina (PRSV-W-P).

\begin{tabular}{|c|c|c|c|c|c|c|}
\hline \multirow[t]{2}{*}{ Tratamentos } & \multirow[t]{2}{*}{$\begin{array}{l}\mathbf{N}^{\circ} \text { de plantas } \\
\text { testadas } *\end{array}$} & \multicolumn{5}{|c|}{$\begin{array}{c}\text { Frequiência de plantas com as } \\
\text { notas de sintomas } * *\end{array}$} \\
\hline & & 1 & 2 & 3 & 4 & 5 \\
\hline PRSV-W-1 & 4 & 4 & & & & \\
\hline PRSV-W-1 + PRSV-W-C & 12 & 12 & & & & \\
\hline Sadia + PRSV-W-C aos 15 dias & 4 & & 2 & & & 2 \\
\hline Sadia + PRSV-W-C aos 25 dias & 4 & & 2 & & & 2 \\
\hline PRSV-W-1 & 6 & 6 & & & & \\
\hline PRSV-W-1 + PRSV-W-B & 18 & 15 & 3 & & & \\
\hline Sadia + PRSV-W-B aos 15 dias & 6 & 2 & & 2 & & 2 \\
\hline Sadia + PRSV-W-B aos 25 dias & 6 & 4 & & & 2 & \\
\hline PRSV-W-1 & 6 & 6 & & & & \\
\hline PRSV-W-1 + PRSV-W-P & 18 & 14 & 4 & & & \\
\hline Sadia + PRSV-W-P aos 15 dias & 6 & 1 & 3 & & & 2 \\
\hline Sadia + PRSV-W-P aos 25 dias & 6 & 2 & 2 & & 2 & \\
\hline
\end{tabular}

*Resultados de dois testes independentes.

**1 = mosaico pouco evidente, sem deformações foliares e bom desenvolvimento.

$5=$ mosaico severo, deformações foliares intensas, bolhas e desenvolvimento reduzido da planta. 
Tabela 4. Recuperação das estirpes do Papaya ringspot virus - type W (PRSV-W) presentes nas folhas (F) inoculadas e/ou desafiadas e nas folhas novas de plantas de melancia 'Crimson Sweet', utilizadas nos testes de proteção com a estirpe fraca PRSV-W-1, contra as estirpes comuns de Campinas (PRSV-W-C), Botucatu (PRSV-W-B) e Petrolina (PRSV-W-P).

\begin{tabular}{|c|c|c|c|c|c|c|c|}
\hline \multirow[t]{2}{*}{ Tratamentos } & \multirow[t]{2}{*}{$\begin{array}{l}\mathrm{N}^{\mathrm{o}} \\
\text { de plantas } \\
\text { testadas }\end{array}$} & \multirow[t]{2}{*}{$\begin{array}{l}\text { Origem do inóculo } \\
\text { p/ recuperação }\end{array}$} & \multicolumn{5}{|c|}{$\begin{array}{l}\mathrm{N}^{\circ} \text { de plantas em função dos sintomas* } \\
\text { induzidos em 'Caserta' pelos inóculos da } \\
\text { recuperação }\end{array}$} \\
\hline & & & $1^{* *}$ & 2 & 3 & 4 & 5 \\
\hline PRSV-W-1 & 4 & F. nova & 4 & & & & \\
\hline PRSV-W-1 + PRSV-W-C & 12 & $\begin{array}{l}\text { F. desafiada } \\
\text { F. nova }\end{array}$ & $\begin{array}{l}12 \\
10\end{array}$ & 2 & & & \\
\hline $\begin{array}{l}\text { Sadia + PRSV-W-C } \\
\text { aos } 15 \text { dias }\end{array}$ & 4 & $\begin{array}{l}\text { F. desafiada } \\
\text { F. nova }\end{array}$ & & & & & $\begin{array}{l}4 \\
4\end{array}$ \\
\hline $\begin{array}{l}\text { Sadia + PRSV-W-C } \\
\text { aos } 25 \text { dias }\end{array}$ & 4 & $\begin{array}{l}\text { F. desafiada } \\
\text { F. nova }\end{array}$ & & & & & $\begin{array}{l}4 \\
4\end{array}$ \\
\hline PRSV-W-1 & 6 & F. nova & 6 & & & & \\
\hline PRSV-W-1 + PRSV-W-B & 18 & $\begin{array}{l}\text { F. desafiada } \\
\text { F. nova }\end{array}$ & $\begin{array}{l}14 \\
13\end{array}$ & 1 & & $\begin{array}{l}2 \\
2\end{array}$ & $\begin{array}{l}2 \\
2\end{array}$ \\
\hline $\begin{array}{l}\text { Sadia + PRSV-W-B } \\
\text { aos } 15 \text { dias }\end{array}$ & 6 & $\begin{array}{l}\text { F. desafiada } \\
\text { F. nova }\end{array}$ & & & & & $\begin{array}{l}6 \\
6\end{array}$ \\
\hline $\begin{array}{l}\text { Sadia + PRSV-W-B } \\
\text { aos } 25 \text { dias }\end{array}$ & 6 & $\begin{array}{l}\text { F. desafiada } \\
\text { F. nova }\end{array}$ & $\begin{array}{l}4 \\
4\end{array}$ & & & $\begin{array}{l}2 \\
2\end{array}$ & \\
\hline PRSV-W-1 & 6 & F. nova & 6 & & & & \\
\hline PRSV-W-1 + PRSV-W-P & 18 & $\begin{array}{l}\text { F. desafiada } \\
\text { F. nova }\end{array}$ & $\begin{array}{l}9 \\
8\end{array}$ & $\begin{array}{l}1 \\
2\end{array}$ & & & $\begin{array}{l}8 \\
8\end{array}$ \\
\hline $\begin{array}{l}\text { Sadia + PRSV-W-P } \\
\text { aos } 15 \text { dias }\end{array}$ & 6 & $\begin{array}{l}\text { F. desafiada } \\
\text { F. nova }\end{array}$ & & & & & $\begin{array}{l}6 \\
6\end{array}$ \\
\hline $\begin{array}{l}\text { Sadia + PRSV-W-P } \\
\text { aos } 25 \text { dias }\end{array}$ & 6 & $\begin{array}{l}\text { F. desafiada } \\
\text { F. nova }\end{array}$ & & & & & $\begin{array}{l}6 \\
6\end{array}$ \\
\hline
\end{tabular}

* 1 = clareamento temporário de nervuras, ausência de mosaico e deformações foliares e bom desenvolvimento a $5=$ mosaico severo, deformações foliares intensas, bolhas e desenvolvimento reduzido da planta.

** Todas as plantas com nota 1 de sintoma tiveram reação positiva em PTA-ELISA com antissoro contra o PRSV-W. 


\subsubsection{Proteção em campo}

No primeiro experimento de proteção em campo, com o cultivar Crimson Sweet, verificou-se que todas as plantas premunizadas com as estirpes PRSV-W-1 e PRSV-W-2 apresentaram bom desenvolvimento, sem sintomas evidentes de mosaico e sem deformações foliares. Os inóculos extraídos dessas plantas e daquelas premunizadas e desafiadas com a estirpe PRSV-W-C induziram sintomas imperceptíveis em 'Caserta', no teste de recuperação. Testes de PTA-ELISA confirmaram a infecção das plantas de abobrinha com o PRSV-W, indicando que a proteção ocorreu em todas as plantas de melancia. Das 10 plantas não protegidas (sadias) e expostas à infecção natural, apenas 2 foram infectadas pela estirpe comum do PRSV-W. As demais permaneceram sadias até o final do teste.

$\mathrm{Na}$ Tabela 5 são apresentados os dados de produção das plantas desse ensaio. Deve-se ressaltar, inicialmente, que das 10 plantas não protegidas, 2 foram infectadas com a estirpe comum da região e tiveram uma produção média de $21,0 \mathrm{Kg}$ de frutos/planta. Já as 8 restantes, que permaneceram sadias, tiveram uma produção média de $32,3 \mathrm{Kg}$ de frutos/planta. Assim sendo, comparando-se a produção média das plantas premunizadas e premunizadas e desafiadas com a daquelas não protegidas, que permaneceram sadias até o final do experimento, nota-se que a premunização trouxe uma redução de 2,4 vezes, aproximadamente, na produção de frutos por planta. Quando comparada com a média das 2 plantas infectadas durante o ciclo da cultura, a redução foi de 1,6 vezes, aproximadamente. 0 efeito negativo da premunização foi mais evidente no tamanho dos frutos do que no número de frutos por planta. $\mathrm{O}$ efeito da estirpe comum do vírus foi mais acentuado quando as plantas foram inoculadas no estádio cotiledonar. Nesse caso, a premunização proporcionou um aumento na produção de 5,0 vezes, aproximadamente. A aparência externa dos frutos foi semelhante em todos os tratamentos. 
Tabela 5. Produção de frutos de plantas de melancia 'Crimson Sweet' em teste de proteção em campo para o controle do Papaya ringspot virus - type $W$ (PRSV-W). Anhembi, SP, 1997.

\begin{tabular}{lccc}
\hline Tratamento* & $\begin{array}{c}\mathbf{N}^{\circ} \text { médio } \\
\text { frutos/planta }\end{array}$ & $\begin{array}{c}\text { Peso médio } \\
\text { do fruto }(\mathrm{Kg})\end{array}$ & $\begin{array}{c}\text { Peso médio de } \\
\text { frutos (Kg)/planta }\end{array}$ \\
\hline PRSV-W-1 & 2,7 & 6,0 & $16,6 \quad \mathrm{a}{ }^{* *}$ \\
PRSV-W-2 & 2,8 & 5,9 & 16,8 a \\
PRSV-W-1 + PRSV-W-C & 2,0 & 7,7 & $15,5 \mathrm{a}$ \\
PRSV-W-2 + PRSV-W-C & 2,1 & 7,4 & $15,7 \quad \mathrm{a}$ \\
PRSV-W-C & 1,4 & 2,6 & $3,8 \mathrm{~b}$ \\
Não protegidas & 2,6 & 11,6 & $30,1 \quad \mathrm{c}$ \\
\hline
\end{tabular}

* PRSV-W-1 = plantas premunizadas com a estirpe fraca PRSV-W-1. PRSV-W-2 = plantas premunizadas com a estirpe fraca PRSV-W-2.

PRSV-W-C = plantas inoculadas com a estirpe comum PRSV-W-C.

PRSV-W-1 + PRSV-W-C = plantas premunizadas e desafiadas com a estirpe comum. PRSV-W-2 + PRSV-W-C = plantas premunizadas e desafiadas com a estirpe comum. Não protegidas = plantas não inoculadas expostas à infecção natural de campo.

** Médias seguidas da mesma letra não diferem a 5\% de probabilidade.

No segundo experimento de proteção em campo, conduzido com os cultivares Crimson Sweet e Crimson Tide, constatou-se contaminação com o ZYMV e o ZLCV. Entre as plantas de 'Crimson Sweet', uma planta premunizada com a estirpe PRSV-W-1 foi contaminada com o ZYMV, enquanto uma planta premunizada com a estirpe PRSV-W-2, 3 premunizadas com o PRSV-W-1, 3 inoculadas com o PRSV-W-C no estádio cotiledonar e 2 não protegidas (sadias) foram contaminadas com o ZLCV. A contaminação das plantas de 'Crimson Tide' ocorreu somente com o ZLCV, em uma planta premunizada com a estirpe PRSV-W-1 e uma inoculada com a estirpe comum PRSV-W-C no estádio cotiledonar. Todas essas plantas foram desconsideradas para os testes de recuperação e análise de dados de produção. 
O teste de recuperação das estirpes do vírus indicaram que todas as plantas premunizadas, dos dois cultivares, estavam infectadas apenas com as estirpes fracas previamente inoculadas. Em nenhum caso foi possível recuperar estirpes comuns do vírus dessas plantas. Entre as plantas não protegidas do cultivar Crimson Sweet, de 8 plantas avaliadas, 3 foram infectadas pela estirpe comum do virus da região e 2 foram premunizadas naturalmente com a estirpe PRSV-W-1 e/ou PRSV-W-2. As 3 plantas restantes permaneceram sadias até o final do ciclo da cultura. No caso do cultivar Crimson Tide, das 10 plantas expostas à infecção natural, 4 foram naturalmente premunizadas, uma foi contaminada com a estirpe comum da região e 5 permaneceram sadias até o final do ciclo da cultura.

$\mathrm{Na}$ Tabela 6 são apresentados os dados de produção do teste de proteção dos cultivares Crimson Sweet e Crimson Tide em campo. No caso das plantas não protegidas, expostas à infecção natural, as 3 plantas de 'Crimson Sweet' infectadas com a estirpe comum do vírus da região tiveram uma produção média de $11,4 \mathrm{Kg}$ de frutos/planta. Já as 2 plantas que foram infectadas com a estirpe fraca PRSV-W-1 e/ou PRSV-W-2 produziram, em média, $15,7 \mathrm{Kg}$ de frutos/planta, enquanto as 3 que permaneceram sadias produziram $9,2 \mathrm{Kg}$ de frutos/planta. Nas plantas não protegidas do cultivar Crimson Tide, a única planta não protegida infectada com a estirpe comum do vírus da região produziu $5,6 \mathrm{Kg}$. As 4 plantas infectadas com a estirpe fraca PRSV-W-1 e/ou PRSV-W-2 produziram a média de 9,6 Kg de frutos/planta. As 5 plantas que permaneceram sadias tiveram uma produção média de $20,2 \mathrm{Kg}$ de frutos/planta. 
Tabela 6. Produção de frutos de plantas de melancia 'Crimson Sweet' e 'Crimson Tide' em testes de proteção em campo para o controle do Papaya ringspot virus - type $W$ (PRSV-W). Anhembi, SP, 1999.

\begin{tabular}{|c|c|c|c|}
\hline Tratamento * & $\begin{array}{l}\mathrm{N}^{\circ} \text { médio } \\
\text { frutos/planta }\end{array}$ & $\begin{array}{l}\text { Peso médio } \\
\text { do fruto }(\mathrm{Kg})\end{array}$ & $\begin{array}{c}\text { Peso médio de } \\
\text { frutos }(\mathrm{Kg}) / \text { planta }\end{array}$ \\
\hline & & Crimson Sweet & \\
\hline PRSV-W-1 & 1,7 & 3,9 & $6,7 \quad a b * *$ \\
\hline PRSV-W-2 & 1,9 & 5,1 & $9,7 \quad a$ \\
\hline PRSV-W-C & 0,9 & 3,1 & $3,1 \quad b$ \\
\hline \multirow[t]{2}{*}{ Não protegidas } & 2,1 & 5,4 & $11,7 \quad a$ \\
\hline & & Crimson Tide & \\
\hline PRSV-W-1 & 1,9 & 6,4 & $12,2 a^{* *}$ \\
\hline PRSV-W-2 & 2,6 & 5,2 & 13,5 a \\
\hline PRSV-W-C & 1,4 & 4,7 & 6,3 a \\
\hline Não protegidas & 2,3 & 6,9 & 16,1 a \\
\hline
\end{tabular}

* PRSV-W-1 = plantas premunizadas com a estirpe fraca PRSV-W-1.

PRSV-W-2 = plantas premunizadas com a estirpe fraca PRSV-W-2.

PRSV-W-C = plantas inoculadas com a estirpe comum PRSV-W-C.

Não protegidas = plantas não inoculadas expostas à infecção natural de campo.

** Médias seguidas da mesma letra não diferem a $5 \%$ de probabilidade.

Mais uma vez a premunização causou redução na produção de frutos por planta, conforme constatado no primeiro teste em campo. As plantas premunizadas do cultivar Crimson Sweet apresentaram redução no peso médio de frutos por planta de, aproximadamente, 1,2 vezes em comparação às plantas não protegidas que permaneceram sadias. Já as plantas inoculadas no estádio cotiledonar com a estirpe comum do vírus não se desenvolveram satisfatoriamente e tiveram a produção drasticamente reduzida. Comparandose a produção média dessas plantas, com a daquelas premunizadas, nota-se que a proteção 
proporcionou um aumento no peso médio de frutos por planta de 2,6 vezes, aproximadamente. As plantas premunizadas do cultivar Crimson Tide também apresentaram uma redução de produção de 1,7 vezes em comparação às plantas não protegidas que permaneceram sadias. Houve, por outro lado, um ganho de 2,0 vezes na produção das plantas premunizadas, sobre a produção das plantas inoculadas no estádio cotiledonar com a estirpe PRSV-W-C. Apesar da redução na produção de frutos colhidos das plantas premunizadas de ambos os cultivares, as estirpes fracas não afetaram de maneira significativa a qualidade dos frutos. A aparência externa dos frutos não foi afetada.

\subsection{DISCUSSÃO}

Os testes de proteção de melancia com as estirpes fracas PRSV-W-1 e PRSV-W-2 mostraram um problema inicial associado com a infecção das plantas na inoculação de premunização. De uma maneira geral, verificou-se que duas inoculações em dias consecutivos foram necessárias para aumentar o número de plantas premunizadas. Mesmo assim, em nenhum caso alcançou-se $100 \%$ de infecção das plantas. Considerando-se que as estirpes fracas PRSV-W-1 e PRSV-W-2 foram selecionadas a partir de bolhas das folhas de abobrinha de moita (C. pepo) com mosaico (Rezende et al., 1994), supõe-se que o problema da baixa infectividade em melancia possa estar associado com a origem e especificidade das estirpes. Problemas de especificidade, associados à origem das estirpes fracas, foram constatados por Costa \& Müller (1980) no controle da tristeza dos citrus por premunização. Nesse caso, entretanto, a especificidade estava associada com a severidade dos sintomas causados pelas estirpes fracas. Estirpes fracas selecionadas de laranjeira 'Pêra', de limoeiro 'Galego' e de pomelos foram específicas para as respectivas espécies. Plantas de limoeiro 'Galego', por exemplo, reagiram com sintomas mais acentuados às estirpes fracas selecionadas de laranjeira 'Pêra' e de pomelo do que para a estirpe fraca selecionada do próprio limoeiro, apesar dessas estirpes oferecerem proteção contra a estirpe do complexo normal. Estudos estão sendo desenvolvidos na tentativa de se selecionar estirpes fracas do vírus que infectem facilmente a melancia e que não causem perdas acentuadas na produção. 
Os dados obtidos nos testes de proteção em casa de vegetação mostraram que algumas plantas de melancia premunizadas foram posteriormente infectadas com as estirpes comuns de Botucatu (PRSV-W-B) e de Petrolina (PRSV-W-P). Não é possível assegurar se esse fato ocorreu devido à quebra de proteção ou ausência da infecção das plantas na inoculação com a estirpe fraca, uma vez que esta não foi confirmada por PTA-ELISA. Há, entretanto, uma sugestão de que a infecção com as estirpes comuns, na maioria das plantas, pode ter ocorrido devido à ausência de infecção com a estirpe fraca. Isto porque, esse problema só foi verificado no primeiro teste. No segundo teste, em que as plantas foram duplamente inoculadas com a estirpe fraca, não foi constatada a recuperação de estirpes comuns do vírus a partir de plantas premunizadas e desafiadas. De uma maneira geral, pode-se dizer que a estirpe fraca PRSV-W-1 protegeu as plantas de melancia e não parece ter afetado o desenvolvimento vegetativo delas.

Nos testes de proteção em campo, verificou-se inicialmente que a pressão de inóculo exercida pelo complexo normal do vírus na região não foi alta. No primeiro teste, apenas 2 plantas, entre 10 não protegidas, foram infectadas pela estirpe comum do PRSV-W. No segundo teste, essa relação foi de 4 em 18 plantas. Deve-se lembrar, todavia, que no primeiro teste, parte das plantas premunizadas foram desafiadas mecanicamente com a estirpe comum PRSV-W-C, 10 dias após o transplante, para confirmar o efeito protetor da premunização. Apesar da baixa pressão de inóculo, verificou-se que as plantas premunizadas ficaram protegidas durante o ciclo da cultura, pois em nenhuma delas foi constatada a presença de estirpes do complexo normal da região, conforme resultados dos testes de recuperação para plantas de 'Caserta'. Apesar da proteção oferecida pelas estirpes fracas, um segundo problema, associado com a premunização de melancia, ficou evidente por ocasião da colheita dos frutos. As plantas premunizadas de 'Crimson Sweet' tiveram uma redução média de 1,5 vezes no peso médio de frutos produzidos, enquanto para as de 'Crimson Tide' essa redução foi de 1,6 vezes, em comparação às plantas não protegidas e que permaneceram sadias.

Este é o primeiro caso em que a premunização de cucurbitáceas, para o controle do mosaico causado pelo PRSV-W, provocou efeito significativamente negativo no volume da produção, apesar da proteção oferecida pelas estirpes fracas. Outros trabalhos de premunização de cucurbitáceas também mostraram redução na produção de plantas 
premunizadas, porém não tão acentuada como a verificada nesse trabalho. Em abobrinha de moita 'Caserta', Rezende \& Pacheco (1998) verificaram que a produção de frutos de plantas protegidas foi $10 \%$ menor do que a daquelas que permaneceram sadias. Relato semelhante foi feito por Lecoq et al. (1991) no controle do ZYMV por premunização, quando detectaram uma redução de $11 \%$ no peso de frutos por planta de abobrinha de moita premunizada, em relação ao daquelas sadias. Montasser et al. (1998), em trabalho de premunização de melão, para o controle do CMV, verificaram que as produções das plantas premunizadas e sadias foram praticamente iguais

Além desses exemplos em que a premunização provocou certa redução na produção, Rezende et al. (1999) também apontaram o efeito dessa tecnologia na qualidade do produto. Plantas de abóbora 'Menina Brasileira', premunizadas contra a PRSV-W, produziram maior porcentagem ( 20 a $25 \%)$ de frutos não comerciais em relação às plantas não protegidas $\mathrm{e}$ infectadas naturalmente pelo complexo normal do vírus (7,5\%). Mesmo assim, os autores verificaram que, no geral, a premunização trouxe um incremento na produção da ordem de $33 \%$. No caso da melancia, não foi observado efeito da premunização na aparência externa dos frutos. Esses fatos mostram que a premunização pode ocasionar alguma redução na produção, bem como na qualidade do produto. Isso é até esperado, uma vez que se tratam de plantas infectadas e que estão desviando parte dos seus metabólitos para a replicação da estirpe fraca premunizante. Essas reduções quantitativas e qualitativas, no entanto, devem ser as menores possíveis, dentro de níveis aceitáveis pelos agricultores.

Apesar dos problemas encontrados na premunização da melancia, é possível que essa tecnologia possa ser valiosa nas regiões e/ou épocas de maior incidência dessa virose. Nesses casos, mesmo havendo redução na produção, ela poderá ser menor do que a obtida na ausência de proteção. A baixa eficiência da inoculação de premunização da melancia, que foi outro problema encontrado, poderá ser compensada por meio da ação dos afideos vetores, que poderão promover a transmissão da estirpe fraca, com a conseqüente premunização de maior número de plantas. Isso, de fato, ocorreu em $33 \%$ das plantas não protegidas dos dois cultivares no segundo experimento em campo. Além disso, como visto no Capítulo 3, a premunização natural foi confirmada experimentalmente nos plantios comerciais de abóbora híbrida do tipo Tetsukabuto, onde $80 \%$ das plantas, aproximadamente, que não foram 
premunizadas mecanicamente no estádio cotiledonar, estavam protegidas no final do ciclo da cultura.

\subsection{CONCLUSÕES}

1- A estirpe fraca PRSV-W-1 protegeu plantas de melancia contra a infecção com as estirpes comuns de Campinas, Botucatu e Petrolina, em testes em casa de vegetação.

2- As estirpes fracas PRSV-W-1 e PRSV-W-2 também protegeram plantas de melancia em campo, porém causaram redução na produção, quando comparada com a das plantas sadias.

3- A maior eficiência de infecção das mudas de melancia com as estirpes fracas do PRSV-W dependeu de duas inoculações mecânicas sucessivas, em dias consecutivos.

\section{CONCLUSÕES GERAIS}

1- As estirpes fracas PRSV-W-1 e PRSV-W-2 protegeram plantas de abóbora híbrida do tipo Tetsukabuto contra a infecção com a estirpe comum de Campinas, em testes em casa de vegetação.

2- A estirpe fraca PRSV-W-1 protegeu plantas de melancia contra a infecção com as estirpes comuns de Campinas, Botucatu e Petrolina, em testes em casa de vegetação.

3- As estirpes fracas PRSV-W-1 e PRSV-W-2 também protegeram plantas de abóbora Tetsukabuto em campo, proporcionando ganhos significativos na produção.

4- As estirpes fracas PRSV-W-1 e PRSV-W-2 também protegeram plantas de melancia em campo, porém causaram redução na produção, quando comparada com a das plantas sadias.

5- A maior eficiência de infecção das mudas de melancia com as estirpes fracas do PRSV-W dependeu de duas inoculações mecânicas sucessivas, em dias consecutivos.

6- A maior eficiência de inoculação massal de mudas de aboboreira híbrida do tipo Tetsukabuto (79\%) foi alcançada aplicando-se o inóculo, juntamente com carborundum, sob pressão de $7,0 \mathrm{Kgf}^{-2}$. 


\section{REFERÊNCIAS BIBLIOGRÁFICAS}

ADLERZ, W.C. Spring aphid flights and incidence of watermelon mosaic virus 1 and 2 in Florida. Phytopathology, v 64, n.1, p.350-353, 1974.

ADLERZ, W.C.; EVERETT, P.H. Aluminum foil and white polyethylene mulches to repel aphids and control watermelon mosaic. Journal of Economic Entomology, v.61, p.1276-1279, 1968.

ALBUQUERQUE, F.C., IKEDA, H., COSTA, A.S. Ocorrência do vírus do mosaico da melancia (Citrullus vulgaris Schrad.) em plantações de melão (Cucumis melo L.) na região de Belém - PA. Revista de Olericultura, v.12, p.94, 1972.

ANUÁRIO ESTATÍSTICO DO BRASIL-1997, v.57, p.38, 1997.

ARCE-OCHOA, J.P.; DAINELLO, F.; PIKE, L.M.; DREWS, D. Field performance comparison of two transgenic summer squash hybrids to their parental hybrid line. HortScience, v.30, n.3, p.492-493, 1995.

BROADBENT, L. Disease control through vector control. In: MARAMOROSCH, K. (Ed.) Virus, Vector and Vegetation. New York: Academic Press, 1969. p.593.

BROWN, J.E.; DANGLER, J.M.; WOODS, F.M.; HENSHAW, M.C.; GRIFFY, W.A.; WEST, M.W. Delay in mosaic virus onset and aphid vector reduction in summer squash grown on reflective mulches. HortScience, v.28, n.9, p.895-896, 1993.

CHALFANT, R.B.; JAWORSKI, C.A.; JOHNSON, A.W.; SUMMER, D.R. Reflective film mulches, millet barriers, and pesticides effects on watermelon mosaic virus, insects, nematodes, soil borne fungi, and yield of yellow summer squash. Journal of the American Society for Horticultural Science, v.102, n. 1, p.11-15, 1977.

CHANNON, A.G.; CHEFFINS, N.J.; HITCHON, G.M.; BARKER, J. The effect of inoculation with an attenuated mutant strain of tobacco mosaic virus on the growth and yield of early glass-house tomato crop. Annals of Applied Biology. v.88, p.121-129, 1978.

CHO, J.J.; ULlMAN, D.E.; WHEATLEY, E.; HOLLY J.; GONSALVES, D.; Commercialization of ZYMV cross protection for zucchini production in Hawaii. Phytopathology, v.82, n.3, p.1073, 1992. 
COSTA, C. L.; COSTA, A. S. Redução na disseminação de mosaico em abóbora de moita (Cucurbita pepo var. melopepo) com superfícies repelentes aos afideos vetores. Revista de Olericultura, v.11, p.24-25, 1971.

COSTA, A.S.; KITAJIMA, E.W.; NAGAI, H. Alguns vírus que afetam o pepino (Cucumis sativus L.) em São Paulo. Revista de Olericultura, v.12, p.100-101. 1972.

COSTA, C. L.; MÜLLER, G. W. Tristeza control by cross protection: a U.S.-Brazil cooperative success. Plant Disease, v.64, n.6, p.538-541. 1980.

CRUZ, E.S.; PAZ, C.D.; PIO-RIBEIRO, G.; BATISTA, D. DA C.; PEREIRA FILHO,G.G.; ANDRADE, G.P. de. Levantamento de viroses em melancia e melão no Submédio São Francisco. Summa Phytopathologica, v.25, n.1, p.21, 1999.

CUPERTINO, F.P.; COSTA, C.L.; KITAIMA, E.W.; MATTOS, J.K.A.; ARAUJO, M.T. Vírus de cucurbitáceas no Distrito Federal. Fitopatologia, v.9, p.51, 1974.

DEMSKI, J.W.; CHALKLEY, J.H. Effect of watermelon mosaic virus on yield and marketability of summer squash. Plant Disease Report, v.56, p.147-150, 1972.

FNP CONSULTORIA \& COMÉRCIO. Agrianual 1999: Anuário da Agricultura Brasileira. São Paulo, 1999. 521 p.

FNP CONSULTORIA \& COMÉRCIO. Agrianual 2000: Anuário da Agricultura Brasileira. São Paulo, 2000. 546 p.

FUCHS, M.; GONSALVES, D. Resistance of transgenic hybrid squash ZW-20 expressing the coat protein genes of Zucchini yellow mosaic virus and Watermelon mosaic virus 2 to mixed infections by both potyviruses. Bio-Technology, v.13, n.13, p.1466-1473, 1995.

FUCHS, M.; McFERSON, J.R.; TRICOLI, D.M.; McMASTER, J.R.; DENG, R.Z.; BOESHORE, M.L.; REYNOLDS, J.F.; RUSSEL, P.F.; QUEMADA, H.D.; GONSALVES, D. Cantaloupe line CZW-30 containing coat protein genes of Cucumber mosaic virus, Zucchini yellow mosaic virus and Watermelon mosaic virus - 2 is resistant to these three viruses in the field. Molecular Breeding, v.3, n.4, p.279-290, 1997.

FULTON, R.W. Practices and precautions in the use of cross protection for plant virus disease control. Annual Review of Phytopathology, v 24, p.67-81, 1986. 
GIAMPAN, J.S. \& REZENDE, J.A.M. Transmissão de estirpes fracas premunizantes do PRSV-W por quatro espécies de afideos. Summa Phytopathologica, v.25, n.1, p.19, 1999.

GLOUGH, G.H.; HAMM, P.B. Coat protein transgenic resistance to watermelon mosaic and Zucchini yellow mosaic virus in squash and cantaloupe. Plant Disease, v.79, n.11, p.1107-1109, 1995.

GREBER, R.S. Watermelon mosaic virus 1 and 2 in Queensland cucurbit crops. Australian Journal of Agriculture, v.29, p.1235-1245, 1978.

GREBER, R.S.; HERRINGTON, M.E. Reaction of interespecific hybrids between Cucurbita ecuadorensis, C. maxima and $C$. moschata to evaluation with cucumber mosaic virus 1 and 2. Australian Plant Pathology, v.9, p. 1-2, 1980.

HERRINGTON, M.E. Yield and quality of Cucurbita maxima increase with delayed infection by papaya ringspot type W. Queensland Journal of Agricultural and Animal Science, v.44, p.117-121, 1987.

HERRINGTON, M.E.; BROWN, P.J.; BYTH, D.E.; TEAKLE, D.S. Inheritance of resistance to Papaya ringspot virus type $W$ in hybrids between Cucurbita ecuadorensis e $C$. maxima (Pumpkin). Australian Journal of Experimental Agriculture, v.29, n.2, p.253-259, 1989.

HERRINGTON, M.E.; PRYTZ, S.; BROWN, P.; PERSLEY, D.M.; GREBER, R. Resistance to Papaya ringspot virus-W, Zucchini yellow mosaic virus and Watermelon mosaic virus 2 in C. maxima. Report - Cucurbit - Genetics - Cooperative, v.14, p.123-124, 1991.

HOJO, H., PAVAN, M.A.; SILVA, N. Agressividade de isolados do vírus do mosaico do mamoeiro - estirpe melancia sobre cultivares de melancia (Citrullus lanatus). Summa Phytopathologica, v.17, n.3, p.188-194, 1991 a.

HOJO, H., SILVA, N.; PAVAN, M.A. Triagem de cultivares de híbridos de melancia para resistência ao vírus do mosaico do mamoeiro estirpe melancia (VMM-Me). Summa Phytopathologica, v.17, n.2, p.113-118, $1991 \mathrm{~b}$.

HUGHES, J. d'A.; OLLENNU, L.A.A. Mild strain protection of cocoa in Ghana against cocoa swollen shoot virus - a review. Plant Pathology, v.43, p.442-457, 1994. 
JONHSON, J. An acquired partial immunity to the tobacco streak disease. Transactions of Wisconsin Academy Science, Arts and Letters, v.30, p.27, 1937.

KITAJIMA, E.W.; RIBEIRO, R.L.D.; LIN, M.T.; RIBEIRO, M.I.S.D.; KIMURA, O.; COSTA, C.L.; PIMENTEL, J.P. Lista comentada de vírus e organismos do tipo micoplasma em plantas cultivadas e silvestres do Estado do Rio de Janeiro. Fitopatologia Brasileira, v.9, p.607, 1984.

KOSAKA, Y.; FUKUNISHI, T. Multiple inoculation with three attenuated viruses for the control of cucumber virus disease. Plant Disease, v.81, n.7, p. 733-738, 1998.

KUABARA, M.Y; COSTA, C.P. Reação de populações segregantes de abobrinha cv. Piramoita (Cucurbita moschata Duch.) ao vírus do mosaico da melancia-1 (WMV-1). Horticultura Brasileira, v.5, n.2, p.34-35, 1987.

KUABARA, M.Y.; SALCEDO, M.J.G.; COSTA, C.P. Fontes de resistência ao vírus do mosaico da melancia - 1 (WMV-1) em abóbora. Horticultura Brasileira, v.5, n.2, p.20-21, 1987.

KUROZAWA, C.; PAVAN, M.A. Doenças das cucurbitáceas (abóbora, abobrinha, chuchu, melancia, melão, moranga, pepino) In: KIMATI, H.; AMORIM, L.; BERGAMIN FILHO, A.; CAMARGO, L.E.A; REZENDE, J.A.M. Manual de fitopatologia: doenças das plantas cultivadas. 3. ed. São Paulo: Agronômica Ceres, 1997. v.2, cap. 29, p. 325-337.

LECOQ, H., LEMAIRE, J.M.; WIPF-SCHEIBEL, C. Control of zucchini yellow mosaic virus in squash by cross protection. Plant Disease, v.75, n.2, p.208-211, 1991.

LECOQ, H., LEMAIRE, J.M; WIPF-SCHEIBEL, C. Control of zucchini yellow mosaic virus in squash by cross protection In: INTERNATIONAL PLANT VIRUS EPIDEMIOLOGY WORKSHOP, 4., Montpellier, 1989. ISPP/SFP, p.113-116.

LIMA, J.A.A., FERNANDES, E.R., MENDES, M.L. Identificação sorológica de "Watermelon mosaic virus 1" em cucurbitáceas cultivadas e nativas do Rio Grande do Norte. Fitopatologia Brasileira, v.5, p.414, 1980.

LIMA, J.A.A., VIEIRA, A.C. Distribuição do vírus do mosaico da abóbora em municípios cearences e gama de hospedeiros de um isolado. Fitopatologia Brasileira, v.17, p.112114. 1992. 
LIN, M.T.; NEMATO, M.; KITAJIMA, E.W. Infecção de melão e maxixe por virus do mosaico da melancia - 1 e vírus do mosaico do pepino em Presidente Wenceslau-SP. In: CONGRESSO BRASILEIRO DE OLERICULTURA, 20., Brasília, 1980. Resumos. p.144.

LOVISOLO, O. Virus and viroid diseases of cucurbits. Acta Horticulture, n.88, p.33-71, 1980.

MALUF, W.R.; SOUSA, E.L.S. Resistência ao vírus do mosaico da melancia-1 (WMV-1) em moranga. Horticultura Brasileira, v.2, n.2, p.22-25, 1984.

McKINNEY, H.H. Mosaic diseases in the Canaty Islands, West Africa and Gibraltar. Journal of Agricultural Research, v.39, p.557-558, 1929.

MONTASSER, M.S., TOUSIGNANT, ME., KAPER, J.M. Virus satellite RNAs for the prevention of cucumber mosaic virus (CMV) disease in field-grown pepper and melon plants. Plant Disease, v.82, n.12, p.1298-1303, 1998.

MOORE, W. D., SMITH, F. F., JOHNSON, G. V.; WOLDENBARGER, W. O. Reduction of aphid population and delayed incidence of virus infection on yellow neck squash by use of aluminum foil. In: Proceedings of Florida State Horticultural Society, v.78, p.187191, 1965.

MOWAT, W.P.; DAWSON, S. Detection of plant viruses by ELISA using crude sap extracts and unfractionated antisera. Journal of Virology Methods, v. 15, p.233-247, 1987.

MÜLLER, G.W.; COSTA, A.S. Tristeza control in Brazil by preimmunization with mild strains. In: Proceedings of the International Society of Citriculture, v.3, p.868-872, 1977.

OLLENNU, L.A.A.; OWUSU, G.K. Isolation and study of mild strain of cocoa swollen shoot virus for possible cross protection. In: Proceedings of the IVth International Plant Virus Epidemiology Workshop, p.119-122, 1989.

OROZCO, S.M.; LOPEZ, A.O.; PEREZ, Z.O.;DELGADILLO, S.F. Effect of transparent mulch, floating row covers and oil sprays on insect populations, virus disease and yield of cantaloupe. Biological Agriculture and Horticulture, v. 10, n.4, p.229-234, 1994. 
PAVAN, M. A. Vírus do mosaico da melancia: purificação, viabilidade e distribuição nas principais regiões produtoras de pepino e abobrinha de Minas Gerais. Viçosa, 1985. 69p. Dissertação (M.S.) - Universidade Federal de Viçosa.

PAVAN, M.A., CARVALHO, M.G., FERNANDES, J.J. Distribuição do virus do mosaico da melancia (papaya ringspot virus - W), nas principais regiões produtoras de pepino (Cucumis sativus) e abobrinha (Cucurbita pepo) de Minas Gerais. Fitopatologia Brasileira, v.14, p.84-85, 1989.

PAVAN, M.A.; SILVA, N. da. Fonte de resistência em melancia ao vírus do mosaico do pepino, VMP. Fitopatologia Brasileira, v.15, p.142, 1990.

PEASLEY, D.; FITZELL, R.D. Passionfruit industry benefits through scion wood scheme. Agriculture Gazette, v.92, p.5-8, 1981.

PARES, R.D.; MARTIN, A.B.; FITZELL, R.D. Virus-induced tip necrosis of passionfruit (Passiflora edulis Sims.). Australian Plant Pathology, v.14, p.76-78, 1985.

PEREIRA, W. Recomendações básicas para a frutificação da abóbora híbrida tipo Tetsukabuto ou Kabutiá: uso de polinizadores e produtos hormonais, Brasília, 14p., 1999. (Embrapa Hortaliças, Comunicado Técnico).

PERRING, T.M.; FARRAR, C.A.; MATTHEW, J.B.; WANG, H.L.; GONSALVES, D. Cross protection of cantaloupe with a mild strain of zucchini yellow mosaic virus: effectiveness and application. Crop Protection, v. 14, n.7, p.601-606, 1995.

PERRING, T.M., ROYALTY, R.N.; FARRAR, C.A. Floating row covers for the exclusion of virus vectors and the effect on disease incidence and yield of cantaloupe. Entomological Society of America, v.6, p.1709-1715, 1989.

POSNETTE, A.F.; TODD, J.Mc.A. Virus diseases of cacao in West Africa. IX. Strain variant and interference in virus 1A. Annals of Applied Biology, v.43, p.433-453, 1955.

PROVVIDENTI, R. Papaya ringspot - W. In: ZITTER, A.; HOPKINS, D.L.; THOMAS, C.E. Compendium of cucurbit diseases. St. Paul: APS Press, 1996. p.40.

PROVVIDENTI, R.; GONSALVES, D. Occurrence of Zucchini yellow mosaic virus in cucurbits from Connecticut. Plant Disease, v.68, n.5, p.443-446, 1984.

PURCIFULL, D.; EDWARDSON, J.; HIEBERT, E.; GONSALVES, D. Papaya ringspot virus. CMI/AAB. Description of plant viruses, n.292, 8p, 1984. 
RAST, A.T.B. MII-16, an artificial symptomless mutant of tobacco mosaic virus for seedling inoculation on tomato crops. Netherland of Journal Plant Pathology, v.28, p.110$112,1972$.

RAST, A.T.B. Variability of tobacco mosaic virus in relation to control of tomato mosaic in glasshouse tomato crops by resistence breeding and cross protection. Agriculture Research Report, n.834, p.1-76, 1975.

REZENDE, J. A. M. Premunização de duas espécies e um híbrido de Cucurbita para o controle do mosaico causado pelo vírus do mosaico do mamoeiro - estirpe melancia. Piracicaba, 1996. 88p. Tese (Livre-Docência) - Escola Superior de Agricultura "Luiz de Queiroz", Universidade de São Paulo.

REZENDE, J.A.M.; MÜLLER, G.W. Mecanismos de Proteção entre vírus e controle de viroses de vegetais por premunização. Revisão Anual de Projetos de Pesquisa, v.3, p.185-226, 1995.

REZENDE, J.A.M.; PACHECO, D.A. Estabilidade de isolados fracos premunizantes do vírus do mosaico - estirpe melancia. Fitopatologia Brasileira, v.22, p.64-68, 1997.

REZENDE, J. A. M.; PACHECO, D. A. Control of papaya ringspot virus-type W in zucchini squash by cross protection in Brazil. Plant Disease, v.82, n.2, p.171-175, 1998.

REZENDE, J. A. M.; PACHECO, D. A.; IEMMA, A.F. Efeitos da premunização da abóbora 'Menina Brasileira' com estirpes fracas do vírus do mosaico do mamoeiro-estirpe melancia. Pesquisa Agropecuária Brasileira, v.34, n.8, p.1481-1489, 1999.

REZENDE, J. A. M.; YUKI, V. A.; VEGA, J.; SCAGLIUSI, S. M. M.; BORBA, L. F.; COSTA, A. S. Isolados fracos do Potyvirus causador do mosaico da abobrinha presentes em bolhas atuam na premunização. Fitopatologia brasileira, v.18, p.55-61, 1994.

ROBINSON, R.W.; DECKER-WALTERS, D.S. Cucurbits., 1997., Wallingford: UK, CAB International, 1997. 226p.

SALAMAN, R.N. Acquired immunity against the "Y" potato virus. Nature, v.139, p.924925, 1937.

SALIBE, A.A. Clones nucelares de Citros no Estado de São Paulo. Laranja, v.2, n.8, p. 443466, 1987. 
SAS INSTITUTE. SAS/STAT user's guide. 4 ed. : Statistical Analyse System Institute, 1990.

SIMONS, J.N.; ZITTER, T.A. Use of oils to control aphid-borne. Plant Disease, v.64, n.6, p.542-546, 1980.

SIMMONDS, J.H. Mild strain protection as a mean of reducing losses from the Queensland woodiness virus in the passion vine. Queensland Journal of Agricultural Science, v.16, p.371-380, 1959.

SITTOLIN, I.M. Tolerância de melancia aos vírus do mosaico amarelo da abobrinha-demoita e do mosaico da melancia-2. Piracicaba, 1998. 72p. Tese (Doutorado) Faculdade de Ciências Agronômicas, Universidade Estadual Paulista "Júlio de Mesquita Filho", Campus de Botucatu.

SUMMERS, C.G.; STAPLETON,J.J.; NEWTON, A.S.; DUNCAN, R.A.; HART, D. Comparison of sprayable and film mulches in delaying the onset of aphid-transmitted virus diseases in zucchini squash. Plant Disease, v. 79, n. 11, p.1126-1131, 1995.

TASAKI, S.; DUSI, A.N. Inheritance of Papaya ringspot virus $W$ strain (Watermelon mosaic virus-1) resistance in the interspecific hybrid between Cucurbita ecuadorensis $\mathrm{x} C$. maxima. Tropical Agriculture Research Series, v.23, p.93-96, 1990.

TIEN, P.; ZHANG, X.; QUI, B.; QIN, B.; WU, G. Satellite RNA for the control of plant diseases caused by cucumber mosaic virus. Annals of Applied Biology, v.111, p. 143$152,1987$.

WALKEY, D.G.A.; LECOQ, H.; COLLIER, R.; DOBSON, S. Studies on the control of zucchini yellow mosaic virus in courgettes by mild strain protection. Plant Pathology, v.41, p.762-71, 1992.

WANG, H. L.; GONSALVES, D.; PROVVIDENTI, R.; LECOQ, H. L. Effectiveness of cross protection by a mild strain of zucchini yellow mosaic virus in cucumber, melon and squash. Plant Disease, v.75, n.2, p.203-207, 1991.

WINGARD, S.A. Host and symptoms of ringspot, a virus disease of plants. Journal of Agricultural Research, v.37, p.127-153, 1928. 
WYMAN, J.A.; TOSCANO, N.C.; KIDO, K.; JOHNSON, H.; MAYBERRY, K. Effects of mulching on the spread of aphid-transmitted watermelon mosaic virus to summer squash. Journal of Economic Entomology, v.72, p. 139-143, 1979.

YARDEN, G.; HEMO, R.; LIVNE, H.; MAOZ, E.; LEV, E.; LECOQ, H.;RACCAH, B. Cross protection of cucurbitaceae from zucchini yellow mosaic potyvirus. In: Proceedings of 7 EUCARPIA Meeting on Cucurbit Genetics and Breeding, n.510, p. 349-356, 2000.

YUKI, V. A. Epidemiologia e controle do mosaico (VMM-Me) em abobrinha-de-moita. Piracicaba, 1990. 84p. Tese (Doutorado) - Escola Superior de Agricultura "Luiz de Queiroz", Universidade de São Paulo.

YUKI, V.A.; COSTA, A.S.; NAGAI, V. Avaliação de perdas induzidas pelo mosaico da abobrinha-de-moita, causado pelo vírus do mosaico do mamoeiro - estirpe melancia (VMM-Me). Summa Phytopathologica, v.17, n.1, p.40, 1991.

YUKI, V.A.; REZENDE, J.A.M.; KITAJIMA, E. W.; BARROSO, P.A.V.; KUNIYUKI, H.; GROPPO, G.A.; PAVAN, M.A. Occurrence, distribution and relative incidence of viruses infecting cucurbits in the State of São Paulo, Brazil. Plant Disease, v.84, n.5, p. $516-520,2000$.

YUKI, V.A.; REZENDE, J.A.M; KUNIYUKI, H.; BETTI, J.A. Fácil transmissão experimental do vírus do mosaico do mamoeiro-estirpe melancia por instrumento de corte em abobrinha de moita. Fitopatologia Brasileira, v.21, p.430, 1996. 